\title{
Cryptic speciation in Protoceratium reticulatum (Dinophyceae): Evidence from morphological, molecular and ecophysiological data
}

\author{
Na Wang ${ }^{\mathrm{a}}$, Kenneth Neil Mertens ${ }^{\mathrm{b}}$, Bernd Krock ${ }^{\mathrm{c}}$, Zhaohe Luo ${ }^{\mathrm{a}}$, Amélie Derrien ${ }^{\mathrm{b}}$, Vera Pospelova ${ }^{\mathrm{d}}$, \\ Yubo Liang ${ }^{\mathrm{e}}$, Gwenael Bilien ${ }^{\mathrm{b}}$, Kirsty F. Smith ${ }^{\mathrm{f}}$, Stijn De Schepper ${ }^{\mathrm{g}}$, Stephan Wietkamp ${ }^{\mathrm{c}}$, \\ Urban Tillmann ${ }^{\mathrm{c}, *}$, Haifeng $\mathrm{Gu}^{\mathrm{a} \text {,* }}$ \\ a Third Institute of Oceanography, Ministry of Natural Resources, Xiamen 361005, China \\ ${ }^{\mathrm{b}}$ Ifremer, LER BO, Station de Biologie Marine, Place de la Croix, BP40537, F-29185 Concarneau CEDEX, France \\ ${ }^{\mathrm{c}}$ Alfred Wegener Institute for Polar and Marine Research, Am Handelshafen 12, D-27570 Bremerhaven, Germany \\ ${ }^{\mathrm{d}}$ School of Earth and Ocean Sciences, University of Victoria, OEASB A405, P. O. Box 170016 STN CSC, Victoria, British Columbia, V8W 2Y2, Canada \\ ${ }^{\mathrm{e}}$ National Marine Environmental Monitoring Center, Ministry of Ecology and Environment, Dalian, 116023, China \\ ${ }^{\mathrm{f}}$ Cawthron Institute, 98 Halifax Street East, Private Bag 2, Nelson 7042, New Zealand \\ ${ }^{\mathrm{g}}$ NORCE Climate, NORCE Norwegian Research Centre AS, Bjerknes Centre for Climate Research, Jahnebakken 5, 5007 Bergen, Norway
}

\section{A R T I C L E I N F O}

\section{Keywords:}

Biogeography

Intraspecific variability

Cysts

Growth

ITS rDNA sequences

Ribotype

Yessotoxin

\begin{abstract}
A B S T R A C T
The cosmopolitan, potentially toxic dinoflagellate Protoceratium reticulatum possesses a fossilizable cyst stage which is an important paleoenvironmental indicator. Slight differences in the internal transcribed spacer ribosomal DNA (ITS rDNA) sequences of $P$. reticulatum have been reported, and both the motile stage and cyst morphology of $P$. reticulatum display phenotypic plasticity, but how these morpho-molecular variations are related with ecophysiological preferences is unknown. Here, 55 single cysts or cells were isolated from localities in the Northern (Arctic to subtropics) and Southern Hemispheres (Chile and New Zealand), and in total 34 strains were established. Cysts and/or cells were examined with light microscopy and/or scanning electron microscopy. Large subunit ribosomal DNA (LSU rDNA) and/or ITS rDNA sequences were obtained for all strains/isolates. All strains/isolates of $P$. reticulatum shared identical LSU sequences except for one strain from the Mediterranean Sea that differs in one position, however ITS rDNA sequences displayed differences at eight positions. Molecular phylogeny was inferred using maximum likelihood and Bayesian inference based on ITS rDNA sequences. The results showed that $P$. reticulatum comprises at least three ribotypes (designated as A, B, and C). Ribotype A included strains from the Arctic and temperate areas, ribotype B included strains from temperate regions only, and ribotype $\mathrm{C}$ included strains from the subtropical and temperate areas. The average ratios of process length to cyst diameter of $P$. reticulatum ranged from $15 \%$ in ribotype A, $22 \%$ in ribotype B and $17 \%$ in ribotype C but cyst size could overlap. Theca morphology was indistinguishable among ribotypes. The ITS-2 secondary structures of ribotype A displayed one CBC (compensatory change on two sides of a helix pairing) compared to ribotypes $\mathrm{B}$ and $\mathrm{C}$. Growth response of one strain from each ribotype to various temperatures was examined. The strains of ribotypes A, B and C exhibited optimum growth at $15{ }^{\circ} \mathrm{C}, 20^{\circ} \mathrm{C}$ and $20-25^{\circ} \mathrm{C}$, respectively, thus corresponding to cold, moderate and warm ecotypes. The profiles of yessotoxins (YTXs) were examined for 25 strains using liquid chromatography coupled with tandem mass spectrometry (LC-MS/MS). The parent compound yessotoxin (YTX) was produced by strains of ribotypes $\mathrm{A}$ and $\mathrm{B}$, but not by ribotype $\mathrm{C}$ strains, which only produced the structural variant homoyessotoxin (homoYTX). Our results support the notion that there is significant intra-specific variability in Protoceratium reticulatum and the biogeography of the different ribotypes is consistent with specific ecological preferences.
\end{abstract}

\section{Introduction}

The planktonic dinoflagellate Protoceratium reticulatum (Claparède \&
Lachmann) Bütschli has a cosmopolitan distribution, and is reported from the Atlantic Ocean, e.g. North Sea, Baltic Sea, the westernmost part of the South Atlantic, East Atlantic of USA, South Africa,

\footnotetext{
* Corresponding authors.

E-mail addresses: urban.tillmann@awi.de (U. Tillmann), guhaifeng@tio.org.cn (H. Gu).
} 
Southwestern Atlantic (Wołoszyńska, 1929; Reinecke, 1967; von Stosch, 1969; Balech, 1988; Dodge, 1989; Paz et al., 2007; Akselman et al., 2015), the Mediterranean Sea (Paz et al., 2007), the Pacific Ocean, e.g. Northern Chile, the Mexican Pacific, northern Japan, northern China, Tasman Sea of Australia (Skerratt et al., 2002; Koike et al., 2006; Hernández-Becerril et al., 2010; Álvarez et al., 2011; Liu et al., 2017), the Arctic, e.g. Greenland (Sala-Pérez et al., 2016), and the Indian Ocean, e.g. Arabian Gulf, East coast of India (Madhav and Kondalarao, 2004; Al Muftah et al., 2016). The species Protoceratium reticulatum is able to form massive blooms, e.g. in Norwegian waters (Braarud et al., 1974; Aasen et al., 2005), South Africa (Reinecke, 1967; Grindley and Nel, 1968), northern Japan (Koike et al., 2006), New Zealand (Satake et al., 1997; MacKenzie et al., 2002), Yellow Sea of China (Liu et al., 2017) and Northern Chile (Álvarez et al., 2011). Blooms of Protoceratium reticulatum have been related to several invertebrate mass mortality events in South Africa (De Wit et al., 2014).

Cysts of $P$. reticulatum were first observed in cultures established from the inner Oslofjord, Norway by Braarud (1945). Recently, the cysts were proven to be produced through sexual reproduction (Salgado et al., 2017). The cyst was initially related to the cyst-defined species described from the Miocene of Australia, Operculodinium centrocarpum (Deflandre \& Cookson) Wall by Wall and Dale (1966, 1967, 1968). However, a restudy of the holotype of $O$. centrocarpum showed that it is much larger than the cyst of $P$. reticulatum (54-80 $\mu \mathrm{m}$ vs $33-37 \mu \mathrm{m})$ and differs in the distal end of processes (fibrous vs hooked), amongst other criteria (Matsuoka et al., 1997). In view of the differences between $O$. centrocarpum and cysts of $P$. reticulatum, the term "Operculodinium centrocarpum sensu Wall and Dale, 1966" is used to refer the cysts that had first been observed by Wall and Dale (1966). Paez-Reyes and Head (2013) suggested that the "cyst of Protoceratium reticulatum" should replace the term "Operculodinium centrocarpum sensu Wall and Dale (1966)".

Cysts of $P$. reticulatum have a cosmopolitan distribution as well (e.g. Zonneveld et al., 2013). Cysts of $P$. reticulatum display distinct variation in morphology, especially its process length; such variations have been related to changes in salinity and/or temperature (Mertens et al., 2011, 2012a, 2012b; Verleye et al., 2012; Jansson et al., 2014). Specimens from the Arctic have distinctly shorter processes and have been designated as Arctic morphotypes ( $=O$. centrocarpum type B of de Vernal et al., 1989) and O. centrocarpum var. cezare (de Vernal et al., 1989, 2001; see also Head, 2007). The Arctic and cezare morphotypes possibly represent morphological gradation of the same taxon (de Vernal et al., 2001) and can be designated as O. centrocarpum var. cezare sensu lato.

An important aspect of $P$. reticulatum is that it can produce yessotoxins (YTXs), together with adriatoxins (Satake et al., 1997; Ciminiello et al., 1998; Domínguez et al., 2010), a collective term for a group of structurally similar marine polyether compounds. The first compound of this group was isolated in 1986 from the digestive gland of scallops in Japan (Murata et al., 1987) and named yessotoxin (YTX) after the scallop, in which it was first detected (Patinopecten yessoensis). Later it was detected in shellfish in Italy, Norway, Chile, New Zealand, USA Pacific, White Sea of Russia, Black Sea, China, Chukchi Sea, and Argentina (Lee et al., 1988; Ciminiello et al., 1997; Yasumoto and Takizawa, 1997; Ciminiello et al., 2002; Aasen et al., 2005; Vershinin et al., 2006; Morton et al., 2007; Howard et al., 2008; Li et al., 2012, 2015; Turner and Goya, 2015). In addition, 92 variants of YTX were reported (Miles et al., 2005a). Most of these variants have structurally not yet been determined and are commonly named yessotoxins (YTXs), unless specific, structurally known variants are referred to e.g. homoyessotoxin (homoYTX). Besides $P$. reticulatum, several other dinoflagellates are known to produce YTXs, including Lingulodinium polyedra (F.Stein) J.D.Dodge, Gonyaulax spinifera (Claparède \& Lachmann) Diesing and Gonyaulax taylorii M.C.Carbonell-Moore (Paz et al., 2004; Riccardi et al., 2009; Álvarez et al., 2016). Even though high acute toxicity after mice intraperitoneal injection has been reported, the mouse toxicity of YTX after oral administration is low and they are regulated by European legislation setting a limit of $3.75 \mathrm{mg}$ YTX equivalents (including YTX, 45-hydroxyYTX, homoYTX and 45-hydroxy-homoYTX) $\mathrm{kg}^{-1}$ shellfish tissue (Commission Regulation [EU] No 786/2013). Recently, homoYTX and 45-hydroxyYTX attributed to Gonyaulax membranacea were reported to be responsible for massive mortality of abalone in South Africa (Pitcher et al., 2019). An oyster mortality in British Columbia, Canada has also been related to yessotoxin production by $P$. reticulatum (Cassis, 2005), although no human illnesses have been linked to high YTX production in Canada (Rourke and Haigh, 2018).

Strains of $P$. reticulatum have been studied based on LSU rDNA sequences, and two clades have been reported (Howard et al., 2009; Akselman et al., 2015). One of these clades was recently shown to be morphologically different from $P$. reticulatum and designated as Pentaplacodinium saltonense K.N.Mertens, M.C.Carbonell-Moore, V.Pospelova \& M.J.Head and Ceratocorys mariaovidiorum P.Salgado, S.Fraga, F.Rodríguez, P.Riobó \& I.Bravo respectively (Mertens et al., 2018a; Salgado et al., 2018). Ceratocorys mariaovidiorum is considered a junior synonym of Pentaplacodinium saltonense (Mertens et al., 2018b).

Slight differences in ITS rDNA sequences have been detected in three cysts of $P$. reticulatum from Japan, Sweden and Pacific Canada and these were attributed to potential pseudocryptic speciation (Mertens et al., 2012a). However, whether these genetic differences are consistent among $P$. reticulatum strains and related with biogeography and physiology, remains to be determined.

Planktonic protists have global scale dispersal potential but environmental and ecological selection seem to play a major role in shaping their spatial and temporal distribution (Martiny et al., 2009; Sohm et al., 2016; Whittaker and Rynearson, 2017). Whether the seemingly cosmopolitan distribution of $P$. reticulatum is a result of genetic, physiological and ecological differentiation has not yet been examined. Here, 55 single cysts or cells were isolated from localities in the Northern Hemisphere (Arctic to subtropics) and Southern Hemisphere (Chile and New Zealand) and 34 strains were established. For each strain/isolate, LSU rDNA and/or ITS rDNA regions were sequenced and the morphology of cysts and cells were examined for some selected strains/isolates. In addition, growth experiments were carried out under various temperatures on three strains and yessotoxins were analyzed for 25 strains.

\section{Material and methods}

\subsection{Sample collection and treatment}

Sediment sampling was done using Ekman, Van Veen or Petite Ponar grabs from the Arctic to the subtropical areas, as well as in Chile and New Zealand from 2014 to 2018 (Table 1, Fig. S1). The top $2 \mathrm{~cm}$ of sediment were sliced off and stored in the dark at $4{ }^{\circ} \mathrm{C}$ until further treatment. Approximately $5 \mathrm{~g}$ of wet sediment was mixed with $20 \mathrm{~mL}$ of filtered seawater and stirred vigorously to dislodge detrital particles. The settled material was subsequently sieved through $120 \mu \mathrm{m}$ and $10 \mu \mathrm{m}$ filters and the residue on the $10 \mu \mathrm{m}$ filter was re-suspended in $1 \mathrm{~mL}$ filtered seawater. Surface water samples were also collected from Dalian (Yellow Sea of China), Greenland and Norway from 2014 to 2017 (Table 1, Fig. S1). Single cysts or cells were isolated with a micropipette and each placed in a single well of a 96-well plate, together with $300 \mu \mathrm{L} \mathrm{f} / 2$-Si medium (Guillard and Ryther, 1962). Conditions for germination and growth were $20^{\circ} \mathrm{C}, 90 \mu \mathrm{E} \mathrm{m}^{-2} \mathrm{~s}^{-1}$ and a $12: 12 \mathrm{~h}$ light: dark cycle (hereafter called 'standard conditions'). Strains isolated from Greenland were grown at $15^{\circ} \mathrm{C}, 50 \mu \mathrm{E} \mathrm{m}^{-2} \mathrm{~s}^{-1}$ under a $16: 8 \mathrm{~h}$ light: dark cycle.

\subsection{Morphological study of thecate stages and cysts}

Live cells or cysts of selected strains were examined and photographed using a Zeiss Axio Imager light microscope (Carl Zeiss, 
Table 1

Strains/isolates of Protoceratium reticulatum examined in the present study, including the ribotype, collection data, coordinates, locality and origin.

\begin{tabular}{|c|c|c|c|c|c|c|c|}
\hline Strains/isolates & LSU/ITS & Ribotype & Collection data & Longitude & Latitude & Location & Origin \\
\hline TIO811 & LSU/ITS & A & $2014 / 7 / 31$ & $168^{\circ} 59.78^{\prime} \mathrm{W}$ & $71^{\circ} 0.45^{\prime} \mathrm{N}$ & Chukchi Sea & Cyst \\
\hline TIO821 & LSU/ITS & A & $2014 / 7 / 31$ & $168^{\circ} 59.78^{\prime} \mathrm{W}$ & $71^{\circ} 0.45^{\prime} \mathrm{N}$ & Chukchi Sea & Cyst \\
\hline TIO829 & LSU/ITS & A & $2014 / 7 / 31$ & $168^{\circ} 59.78^{\prime} \mathrm{W}$ & $71^{\circ} 0.45^{\prime} \mathrm{N}$ & Chukchi Sea & Cyst \\
\hline TIO839 & LSU & NA & $2014 / 7 / 31$ & $168^{\circ} 59.78^{\prime} \mathrm{W}$ & $71^{\circ} 0.45^{\prime} \mathrm{N}$ & Chukchi Sea & Cyst \\
\hline WN01" & LSU & NA & $2014 / 7 / 31$ & $168^{\circ} 59.78^{\prime} \mathrm{W}$ & $71^{\circ} 0.45^{\prime} \mathrm{N}$ & Chukchi Sea & Cyst \\
\hline WN160" & ITS & A & $2014 / 7 / 31$ & $168^{\circ} 59.78^{\prime} \mathrm{W}$ & $71^{\circ} 0.45^{\prime} \mathrm{N}$ & Chukchi Sea & Cyst \\
\hline WN162* & ITS & $\mathrm{A}$ & $2014 / 7 / 31$ & $168^{\circ} 59.78^{\prime} \mathrm{W}$ & $71^{\circ} 0.45^{\prime} \mathrm{N}$ & Chukchi Sea & Cyst \\
\hline WN82* & ITS & A & $2014 / 7 / 31$ & $168^{\circ} 57.47^{\prime} \mathrm{W}$ & $72^{\circ} 0.60^{\prime} \mathrm{N}$ & Chukchi Sea & Cyst \\
\hline WN84* & ITS & A & $2014 / 7 / 31$ & $167^{\circ} 57.58^{\prime} \mathrm{W}$ & $73^{\circ} 0.00^{\prime} \mathrm{N}$ & Chukchi Sea & Cyst \\
\hline WN87" & ITS & $\mathrm{A}$ & $2014 / 8 / 1$ & $168^{\circ} 57.82^{\prime} \mathrm{W}$ & $74^{\circ} 0.05^{\prime} \mathrm{N}$ & Chukchi Sea & Cyst \\
\hline WN88* & ITS & A & $2014 / 8 / 1$ & $168^{\circ} 57.64^{\prime} \mathrm{W}$ & $74^{\circ} 36.73^{\prime} \mathrm{N}$ & Chukchi Sea & Cyst \\
\hline WN90" & ITS & A & $2014 / 8 / 8$ & $167^{\circ} 53.30^{\prime} \mathrm{W}$ & $75^{\circ} 26.45^{\prime} \mathrm{N}$ & Chukchi Sea & Cyst \\
\hline WN79" & ITS & A & $2016 / 5 / 19$ & $122^{\circ} 43.98^{\prime} \mathrm{E}$ & $39^{\circ} 02.43^{\prime} \mathrm{N}$ & Dalian, Yellow Sea & Cyst \\
\hline WN92* & ITS & $\mathrm{A}$ & $2016 / 5 / 19$ & $122^{\circ} 43.98^{\prime} \mathrm{E}$ & $39^{\circ} 02.43^{\prime} \mathrm{N}$ & Dalian, Yellow Sea & Cyst \\
\hline WN93* & ITS & A & $2016 / 5 / 19$ & $122^{\circ} 43.98^{\prime} \mathrm{E}$ & $39^{\circ} 02.43^{\prime} \mathrm{N}$ & Dalian, Yellow Sea & Cyst \\
\hline WN97* & ITS & A & $2016 / 5 / 19$ & $122^{\circ} 43.98^{\prime} \mathrm{E}$ & $39^{\circ} 02.43^{\prime} \mathrm{N}$ & Dalian, Yellow Sea & Cyst \\
\hline WN99" & ITS & A & $2016 / 5 / 19$ & $122^{\circ} 43.98^{\prime} \mathrm{E}$ & $39^{\circ} 02.43^{\prime} \mathrm{N}$ & Dalian, Yellow Sea & Cyst \\
\hline WN100* & ITS & A & $2016 / 5 / 19$ & $122^{\circ} 43.98^{\prime} \mathrm{E}$ & $39^{\circ} 02.43^{\prime} \mathrm{N}$ & Dalian, Yellow Sea & Cyst \\
\hline Weining & LSU/ITS & A & $2014 / 2 / 10$ & $122^{\circ} 36.00^{\prime} \mathrm{E}$ & $38^{\circ} 54.00^{\prime} \mathrm{N}$ & Dalian, Yellow Sea & Cell \\
\hline MP-B06 & LSU & NA & $2017 / 7 / 15$ & $51^{\circ} 41.98^{\prime} \mathrm{W}$ & $69^{\circ} 10.00^{\prime} \mathrm{N}$ & Disko Bay, Greenland & Cell \\
\hline MP-D11 & LSU & NA & $2017 / 7 / 2$ & $51^{\circ} 07.00^{\prime} \mathrm{W}$ & $64^{\circ} 43.31^{\prime} \mathrm{N}$ & Godhabsfjord, Greenland & Cell \\
\hline MP-F05 & LSU/ITS & A & $2017 / 7 / 2$ & $51^{\circ} 07.00^{\prime} \mathrm{W}$ & $64^{\circ} 43.31^{\prime} \mathrm{N}$ & Godhabsfjord, Greenland & Cell \\
\hline MP-F06 & LSU/ITS & $\mathrm{A}$ & $2017 / 7 / 2$ & $51^{\circ} 07.00^{\prime} \mathrm{W}$ & $64^{\circ} 43.31^{\prime} \mathrm{N}$ & Godhabsfjord, Greenland & Cell \\
\hline MP-S-D1 & LSU/ITS & A & $2017 / 7 / 16$ & $51^{\circ} 43.78^{\prime} \mathrm{W}$ & $68^{\circ} 42.83^{\prime} \mathrm{N}$ & Disko Bay, Greenland & Cell \\
\hline MP-S-F7 & LSU & NA & $2017 / 7 / 16$ & $51^{\circ} 43.78^{\prime} \mathrm{W}$ & $68^{\circ} 42.83^{\prime} \mathrm{N}$ & Disko Bay, Greenland & Cell \\
\hline PR2\# & KT906408/ITS & A & $2012 / 8 / 2$ & $44^{\circ} 41.27^{\prime} \mathrm{W}$ & $59^{\circ} 43.38^{\prime} \mathrm{N}$ & Greenland, Southern Tip & Cell \\
\hline PR3\# & KT906409/ITS & A & $2012 / 7 / 30$ & $54^{\circ} 6.21^{\prime} \mathrm{W}$ & $69^{\circ} 11.95^{\prime} \mathrm{N}$ & Disko Bay, Greenland & Cell \\
\hline PR4\# & KT906410/ITS & A & $2012 / 7 / 30$ & $54^{\circ} 6.21^{\prime} \mathrm{W}$ & $69^{\circ} 11.95^{\prime} \mathrm{N}$ & Disko Bay, Greenland & Cell \\
\hline $17-381$ & LSU/ITS & A & $2017 / 6 / 9$ & $5^{\circ} 16.47^{\prime} \mathrm{E}$ & $60^{\circ} 18.77^{\prime} \mathrm{N}$ & Nordasvatnet, Bergen, Norway & Cell \\
\hline $17-385$ & LSU/ITS & A & $2017 / 6 / 9$ & $5^{\circ} 16.47^{\prime} \mathrm{E}$ & $60^{\circ} 18.77^{\prime} \mathrm{N}$ & Nordasvatnet, Bergen, Norway & Cell \\
\hline $18-760$ & LSU/ITS & A & $2017 / 9 / 7$ & $56^{\circ} 8.67^{\prime} \mathrm{W}$ & $46^{\circ} 47.58^{\prime} \mathrm{N}$ & Saint-Pierre et Miquelon, France & Cyst \\
\hline $18-700$ & LSU/ITS & A & $2017 / 9 / 26$ & $123^{\circ} 18.06^{\prime} \mathrm{W}$ & $48^{\circ} 25.51^{\prime} \mathrm{N}$ & Oak Bay, BC, Canada & Cyst \\
\hline TIO893 & LSU/ITS & B & $2017 / 3 / 5$ & $123^{\circ} 28.31^{\prime} \mathrm{W}$ & $48^{\circ} 39.30^{\prime} \mathrm{N}$ & Patricia Bay, Saanich Inlet, Canada & Cyst \\
\hline TIO899 & LSU/ITS & B & $2017 / 3 / 5$ & $123^{\circ} 28.31^{\prime} \mathrm{W}$ & $48^{\circ} 39.30^{\prime} \mathrm{N}$ & Patricia Bay, Saanich Inlet, Canada & Cyst \\
\hline TIO440 & LSU/ITS & B & $2016 / 12 / 9$ & $72^{\circ} 25.41^{\prime} \mathrm{W}$ & $42^{\circ} 22.91^{\prime} \mathrm{S}$ & Comau Fjord, Chile & Cyst \\
\hline TIO519 & LSU/ITS & B & $2018 / 2 / 18$ & $174^{\circ} 12.14^{\prime} \mathrm{E}$ & $41^{\circ} 16.04^{\prime} \mathrm{S}$ & Oyster Bay, New Zealand & Cyst \\
\hline TIO520 & LSU/ITS & B & $2018 / 2 / 18$ & $174^{\circ} 12.14^{\prime} \mathrm{E}$ & $41^{\circ} 16.04^{\prime} \mathrm{S}$ & Oyster Bay, New Zealand & Cyst \\
\hline WN171" & ITS & B & $2018 / 2 / 18$ & $174^{\circ} 12.14^{\prime} \mathrm{E}$ & $41^{\circ} 16.04^{\prime} \mathrm{S}$ & Oyster Bay, New Zealand & Cyst \\
\hline WN175* & ITS & B & $2018 / 2 / 18$ & $174^{\circ} 12.14^{\prime} \mathrm{E}$ & $41^{\circ} 16.04^{\prime} \mathrm{S}$ & Oyster Bay, New Zealand & Cyst \\
\hline WN176" & ITS & B & $2018 / 2 / 18$ & $174^{\circ} 12.14^{\prime} \mathrm{E}$ & $41^{\circ} 16.04^{\prime} \mathrm{S}$ & Oyster Bay, New Zealand & Cyst \\
\hline WN178 & ITS & B & $2018 / 2 / 18$ & $174^{\circ} 12.14^{\prime} \mathrm{E}$ & $41^{\circ} 16.04^{\prime} \mathrm{S}$ & Oyster Bay, New Zealand & Cyst \\
\hline WN181" & ITS & B & $2018 / 2 / 18$ & $174^{\circ} 12.14^{\prime} \mathrm{E}$ & $41^{\circ} 16.04^{\prime} \mathrm{S}$ & Oyster Bay, New Zealand & Cyst \\
\hline WN182 & ITS & B & $2018 / 2 / 18$ & $174^{\circ} 12.14^{\prime} \mathrm{E}$ & $41^{\circ} 16.04^{\prime} \mathrm{S}$ & Oyster Bay, New Zealand & Cyst \\
\hline TIO707 & LSU/ITS & $\mathrm{C}$ & $2016 / 1 / 18$ & $9^{\circ} 31.72^{\prime} \mathrm{E}$ & $42^{\circ} 7.66^{\prime} \mathrm{N}$ & Corsica, France (Mediterranean) & Cyst \\
\hline TIO831 & LSU/ITS & $\mathrm{C}$ & $2016 / 5 / 19$ & $122^{\circ} 43.98^{\prime} \mathrm{E}$ & $39^{\circ} 02.43^{\prime} \mathrm{N}$ & Dalian, Yellow Sea, China & Cyst \\
\hline TIO853 & LSU/ITS & $\mathrm{C}$ & $2016 / 5 / 19$ & $122^{\circ} 43.98^{\prime} \mathrm{E}$ & $39^{\circ} 02.43^{\prime} \mathrm{N}$ & Dalian, Yellow Sea, China & Cyst \\
\hline TIO858 & LSU/ITS & $\mathrm{C}$ & $2016 / 5 / 19$ & $122^{\circ} 43.98^{\prime} \mathrm{E}$ & $39^{\circ} 02.43^{\prime} \mathrm{N}$ & Dalian, Yellow Sea, China & Cyst \\
\hline WN101* & ITS & $\mathrm{C}$ & $2016 / 5 / 19$ & $122^{\circ} 43.98^{\prime} \mathrm{E}$ & $39^{\circ} 02.43^{\prime} \mathrm{N}$ & Dalian, Yellow Sea, China & Cyst \\
\hline TIO238 & LSU & NA & $2016 / 1 / 3$ & $121^{\circ} 3.98^{\prime} \mathrm{E}$ & $27^{\circ} 27.57^{\prime} \mathrm{N}$ & Wenzhou, East China Sea, China & Cyst \\
\hline TIO239 & LSU/ITS & $\mathrm{C}$ & $2016 / 1 / 3$ & $121^{\circ} 3.98^{\prime} \mathrm{E}$ & $27^{\circ} 27.57^{\prime} \mathrm{N}$ & Wenzhou, East China Sea, China & Cyst \\
\hline TIO240 & LSU & NA & $2016 / 1 / 3$ & $121^{\circ} 3.98^{\prime} \mathrm{E}$ & $27^{\circ} 27.57^{\prime} \mathrm{N}$ & Wenzhou, East China Sea, China & Cyst \\
\hline TIO269 & LSU/ITS & $\mathrm{C}$ & $2016 / 3 / 30$ & $119^{\circ} 25.20^{\prime} \mathrm{E}$ & $25^{\circ} 3.66^{\prime} \mathrm{N}$ & East China Sea, China & Cyst \\
\hline TIO863 & LSU/ITS & $\mathrm{C}$ & $2017 / 4 / 11$ & $109^{\circ} 6.05^{\prime} \mathrm{E}$ & $21^{\circ} 0.64^{\prime} \mathrm{N}$ & Weizhou, South China Sea, China & Cyst \\
\hline TIO864 & LSU/ITS & $\mathrm{C}$ & $2017 / 4 / 11$ & $109^{\circ} 6.05^{\prime} \mathrm{E}$ & $21^{\circ} 0.64^{\prime} \mathrm{N}$ & Weizhou, South China Sea, China & Cyst \\
\hline TIO865 & LSU & NA & $2017 / 4 / 11$ & $109^{\circ} 6.05^{\prime} \mathrm{E}$ & $21^{\circ} 0.64^{\prime} \mathrm{N}$ & Weizhou, South China Sea, China & Cyst \\
\hline
\end{tabular}

* Cysts were sequenced directly without germination; \# Sala-Pérez et al., 2016.

Göttingen, Germany) equipped with a Zeiss Axiocam HRc digital camera. The cell size of $13-40$ cells of selected strains was measured using Axiovision (4.8.2 version) software at $\times 1000$ magnification. Twenty-one cysts from the field were measured and sequenced directly without germination.

For scanning electron microscopy (SEM), mid-exponential batch cultures of strains TIO238, TIO239, TIO440, TIO519, TIO853 and Weining were concentrated by a Universal $320 \mathrm{R}$ centrifuge (HettichZentrifugen, Tuttlingen, Germany) at $850 \mathrm{~g}$ for $10 \mathrm{~min}$ at room temperature. Cells were fixed with $2.5 \%$ glutaraldehyde for $3 \mathrm{~h}$ at $8{ }^{\circ} \mathrm{C}$, rinsed with Milli-Q water twice and post-fixed with $1 \% \mathrm{OsO}_{4}$ overnight at $8{ }^{\circ} \mathrm{C}$. The supernatant was removed and the settled cells were transferred to a coverslip coated with poly-L-lysine (molecular weight $70,000-150,000)$. The cells attached to the cover slip were rinsed with
Milli-Q water twice. The samples were then dehydrated in a graded ethanol series $(10 \%, 30 \%, 50 \%, 70 \%, 90 \%$ and $3 \times$ in $100 \%, 10 \mathrm{~min}$ at each step), critical point dried (K850 Critical Point Dryer, Quorum/ Emitech, West Sussex, UK), sputter-coated with gold, and examined with a Zeiss Sigma FE (Carl Zeiss Inc., Oberkochen, Germany) scanning electron microscope at Xiamen University, China. Labelling of tabulation follows a modified Kofoid system that recognizes homologs (e.g. Fensome et al., 1993). The sulcal plate labeling is according to Balech (1980).

\subsection{PCR amplifications and sequencing}

Single cells or cysts were isolated and washed several times with sterile distilled water. They were broken using a coverslip on top and 
Table 2

Mass transitions of the selected reaction monitoring (SRM) LC-MS/MS experiments and their respective YTX designations cited in Sala-Pérez et al. (2016). All compounds and entries refer to original numbering in Miles et al. (2005a, b).

\begin{tabular}{|c|c|c|}
\hline $\begin{array}{l}\text { Q1 mass } \\
(m / z)\end{array}$ & $\begin{array}{l}\text { Q3 mass } \\
(m / z)\end{array}$ & YTX \\
\hline 991 & 911 & Compounds 17-19 \\
\hline 1047 & 967 & $\begin{array}{l}\text { 41-keto-YTX, 40-epi-41-keto-YTX; 41-keto-YTX- } \\
\text { enone (compounds 6,7,8) }\end{array}$ \\
\hline 1049 & 969 & Undescribed \\
\hline 1061 & 981 & Entries 21, 22 \\
\hline 1085 & 1005 & Compound 16 \\
\hline 1101 & 1021 & Nor-YTX (compound 5) \\
\hline 1117 & 1037 & Entry 17 \\
\hline 1131 & 1051 & Undescribed \\
\hline 1141 & 1061 & YTX, entries (32-35) \\
\hline 1143 & 1063 & Entry 37 \\
\hline 1155 & 1075 & 41a-homo-YTX (compound 5) \\
\hline 1157 & 1077 & 45-OH-YTX (compound 2) \\
\hline 1159 & 1079 & Entry 45 \\
\hline 1169 & 1089 & 9-Me-41a-homo-YTX (compound 10) \\
\hline 1171 & 1091 & Undescribed \\
\hline
\end{tabular}

used as templates for PCR amplification. Alternatively, total DNA was extracted from cultured cells. PCR amplifications were carried out using $1 \times$ PCR buffer, $50 \mu \mathrm{M}$ dNTP mixture, $0.2 \mu \mathrm{M}$ of each primer, and $1 \mathrm{U}$ of ExTaq DNA Polymerase (Takara, Tokyo, Japan) in $50 \mu \mathrm{L}$ reactions. The LSU rDNA was amplified using the primers D1R/28-1483R (Scholin et al., 1994; Daugbjerg et al., 2000). The total ITS1-5.8S-ITS2 was amplified using ITSA/ITSB primers (Adachi et al., 1996). The thermal cycle procedure was $4 \mathrm{~min}$ at $94^{\circ} \mathrm{C}$, followed by 30 cycles of $1 \mathrm{~min}$ at $94^{\circ} \mathrm{C}, 1 \mathrm{~min}$ at $45^{\circ} \mathrm{C}, 1 \mathrm{~min}$ at $72^{\circ} \mathrm{C}$, and final extension of $7 \mathrm{~min}$ at $72{ }^{\circ} \mathrm{C}$ with a Mastercycler (Eppendorf, Hamburg, Germany). The PCR product was purified using a DNA purification kit (Shengong, Shanghai, China) and sequenced directly in both directions on an ABI PRISM 3730XL (Applied Biosystems, Foster City, CA, USA) following the manufacturer's instructions. For strains isolated from Greenland, PCR reactions and sequencing conditions were set according to Tillmann et al. (2017), and PCR product purification was done by using the NucleoSpin Gel and PCR clean-up kit (Macherey-Nagel, Düren, Germany). Newly obtained sequences were deposited in GenBank with accession numbers MK811135 to MK811181 (ITS rDNA) and MK814167 to MK814184 (partial LSU rDNA). For strains from Oak Bay (Canada), Bergen (Norway), and Saint-Pierre-et-Miquelon (overseas collectivity of France), a similar method was used (e.g. Mertens et al., 2012a).

\subsection{Sequence alignment and phylogenetic analysis}

Newly obtained ITS rDNA sequences were added to available Protoceratium reticulatum sequences in GenBank. Sequences were aligned using MAFFT v7.110 (Katoh and Standley, 2013) online program (http://mafft.cbrc.jp/alignment/server/) with default settings. Alignments were manually checked with BioEdit v. 7.0.5 (Hall, 1999). Completed alignments were saved as NEXUS files and imported into PAUP *4b10 software (Swofford, 2002) so that divergence rates could be estimated using simple uncorrected pairwise (p) distance matrices. For Bayesian inference (BI), the program jModelTest (Posada, 2008) was used to select the most appropriate model of molecular evolution with Akaike Information Criterion (AIC). Bayesian reconstruction of the data matrix was performed using MrBayes 3.2 (Ronquist and Huelsenbeck, 2003) with the best-fitting substitution model (GTR + G). Four Markov chain Monte Carlo (MCMC) chains ran for 6,000,000 generations, sampling every 100 generations. The first $10 \%$ of burn-in trees were discarded. A majority rule consensus tree was created in order to examine the posterior probabilities of each clade. Maximum likelihood (ML) analyses were conducted with RaxML v7.2.6
Table 3

Mass transitions of the multiple reaction monitoring (MRM) LC-MS/MS experiments.

\begin{tabular}{lll}
$\begin{array}{l}\text { Q1 mass }(m / z) \\
{[\mathrm{M}-2 \mathrm{H}]^{2-}}\end{array}$ & Q3 mass $(m / z)$ & Toxins \\
550.4 & $396.4 ; 467.4$ & Trinor YTX \\
557.4 & $403.4 ; 474.4$ & Trinor homo YTX \\
565.4 & $396.4 ; 467.4$ & 45OH-dinor-YTX, 41a-homo-44oxotrinor \\
570.4 & $396.4 ; 467.4$ & YTX \\
577.4 & $403.4 ; 474.4$ & Homo YTX \\
578.4 & $396.4 ; 467.4$ & 45-OH YTX \\
585.4 & $403.4 ; 474.4$ & Homo 45-OH YTX \\
586.4 & $396.4 ; 467.4$ & COOH YTX \\
593.4 & $403.4 ; 474.4$ & Homo COOH YTX \\
594.4 & $396.4 ; 467.4$ & COOH 45-OH YTX \\
594.4 & $403.4 ; 474.4$ & Homo 44,45-diOH YTX \\
636.4 & $396.4 ; 533.4$ & 32-O-monoglycosyl YTX \\
702.4 & $396.4 ; 599.4$ & 32-O-diglycosyl YTX \\
\hline
\end{tabular}

(Stamatakis, 2006) on the T-REX web server (Boc et al., 2012) using the model GTR + G. Node support was assessed with 1000 bootstrap replicates.

Using Hidden Markov Models for the flanking 5.8 and 28S rDNA regions, ITS-2 boundaries can be precisely detected (Keller et al., 2009). The secondary structures of ITS-2 rDNA sequences of 3 strains of Protoceratium reticulatum were predicted using RNAstructure version 6.0.1 (http://rna.urmc.rochester.edu/RNAstructureWeb/Servers/Predict1/ Predict1.html).

\subsection{Analysis of yessotoxins}

A total of 23 different strains were grown in $200 \mathrm{~mL}$ Erlenmeyer flasks under standard culture conditions or at $15^{\circ} \mathrm{C}, 50 \mu \mathrm{E} \mathrm{m}{ }^{-2} \mathrm{~s}^{-1}$ and under a 16:8 h light: dark cycle for Greenland strains. At stationary phase about $10^{5}$ cells were collected by centrifugation. Algal pellets for quantification of intracellular YTXs were transferred to $2 \mathrm{~mL}$ microcentrifuge tubes and stored at $-20^{\circ} \mathrm{C}$ until analysis.

Pellets were extracted with $0.5 \mathrm{~mL}$ of methanol $(\mathrm{MeOH})$ using a FastPrep1 FP120 Cell Disrupter for $45 \mathrm{~s}$ at $6.5 \mathrm{~m} \mathrm{~s}^{-1}$ by reciprocal shaking, then the samples were centrifuged at $3200 \times g$ for $15 \mathrm{~min}$. The supernatant was transferred to a $1 \mathrm{~mL}$ tube using a spin filter with a pore diameter of $0.45 \mu \mathrm{m}$ and centrifuged at $9300 \times g$ for $30 \mathrm{~s}$. Samples were stored at $-20{ }^{\circ} \mathrm{C}$ in autosampler vials until measurement by LC-MS/MS

Measurements were carried out on a triple quadruple mass spectrometer (API 4000 QTrap, Sciex) with turbo spray ionization in the negative mode. Separation was performed on a reversed phase BDS C8 column $(50 \times 2 \mathrm{~mm}, 3 \mathrm{~mm}, 120 \mathrm{~A})$ at a flow rate of $0.3 \mathrm{~mL} \mathrm{~min}^{-1}$ using an elution gradient with two eluents (A: water and B: $95 \%$ acetonitrile/ methanol $(1: 2 \mathrm{v} / \mathrm{v})$ and $5 \%$ water, both eluents containing $2.0 \mathrm{mM}$ ammonium formate and $50 \mathrm{mM}$ formic acid). Initial composition was $40 \%$ B. A linear gradient to $100 \%$ B was performed from 0 to $6 \mathrm{~min}$ followed by isocratic elution with $100 \%$ B until $15 \mathrm{~min}$, then returning to initial conditions until $16 \mathrm{~min}$ and $12 \mathrm{~min}$ column equilibration (total run time $28 \mathrm{~min}$ ). Yessotoxins were detected in the selected reaction monitoring (SRM) mode and the transitions shown in Table 2 were used. The parent compound yessotoxin was identified by comparing retention times and mass transitions of samples and a reference standard (IMB-NRC, Halifax, Canada). All other yessotoxins were assigned according to Miles et al. (2005a, b) and calibrated against the YTX standard and expressed as YTX equivalents. Results are expressed as YTX cell quota (pg YTX cell ${ }^{-1}$ ).

For the two strains from Saint-Pierre-et-Miquelon and Oak Bay, Mixer Ball Milling equipment (Mixer Mill MM400, Retsch) was used to extract YTXs from small numbers of isolated cells. Methanol $(200 \mu \mathrm{L})$ was added to the isolated cells and was transferred in a $1.5 \mathrm{~mL}$ Safelock 


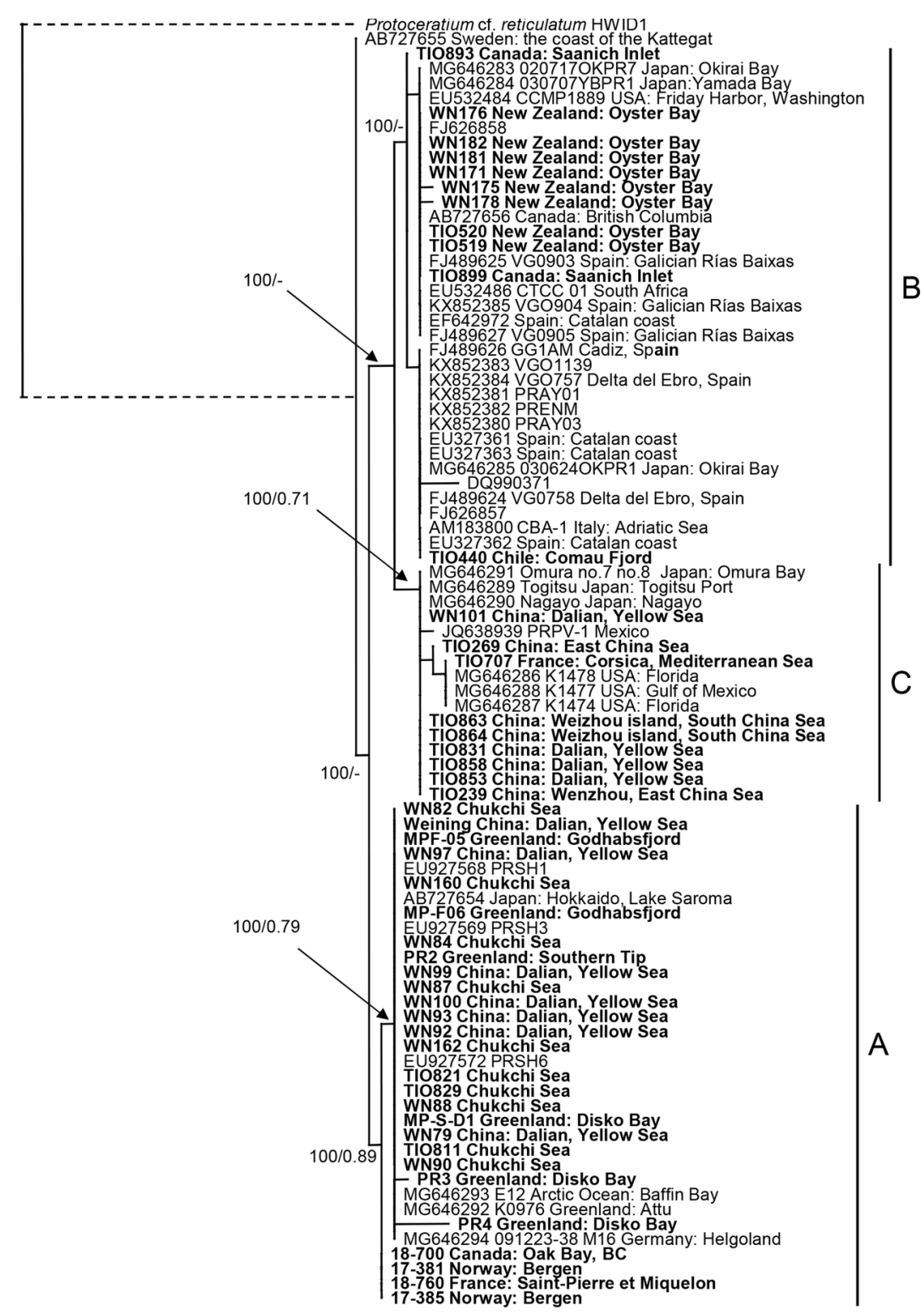

0.01

Fig. 1. Phylogeny of Protoceratium reticulatum inferred from ITS rDNA sequences (524 bp, including 5.8S rDNA sequences) using maximum likelihood (ML). New sequences are indicated in bold. Three ribotypes (A, B and C) are labeled and marked with vertical lines on the right. Branch lengths are drawn to scale, with the scale bar indicating the number of nucleotide substitutions per site. Numbers on branches are statistical support values to clusters on the right of them (left: ML bootstrap support values; right: Bayesian posterior probabilities). Dashed lines indicate half length.

Table 4

Pairwise genetic distances based on ITS rDNA sequences among Protoceratium reticulatum strains.

\begin{tabular}{lllllll}
\hline & TIO239 & TIO707 & TIO440 & TIO519 & TIO811 & AB727655 \\
\hline Protoceratium reticulatum TIO239 & & & & & & \\
Protoceratium reticulatum TIO707 & 0.00 & & & & & \\
Protoceratium reticulatum TIO440 & 0.01 & 0.01 & & & & \\
Protoceratium reticulatum TIO519 & 0.01 & 0.01 & 0.00 & 0.01 & 0.01 & \\
Protoceratium reticulatum TIO811 & 0.01 & 0.02 & 0.01 & 0.01 & 0.20 \\
Protoceratium reticulatum AB727655 & 0.01 & 0.01 & 0.01 & 0.20 & \\
Protoceratium cf. reticulatum HWDI & 0.20 & 0.21 & 0.20 & & \\
\hline
\end{tabular}

Eppendorf. Glass beads (150 mg, 100-250 $\mu \mathrm{m}$ in diameter) were added to the solvent. Samples were shaken at $30 \mathrm{~Hz}$ for at least $40 \mathrm{~min}$. After centrifugation at $15,000 \mathrm{~g}$, the supernatant was ultrafiltered $(0.20 \mu \mathrm{m}$, Nanosep MF, Pall) and transferred into an HPLC vial before LC-MS/MS analyses. Sample analyses were performed by LC-MS/MS using a
Shimadzu UFLCxr system coupled to a triple quadruple hybrid mass spectrometer Q-Trap (API400QTrap, Sciex) equipped with a heated electrospray ionization (ESI) source. Data acquisitions were performed in negative ion mode and using MRM (Multiple Reaction Monitoring) mode. Chromatographic separation was carried out on a reversed-phase 


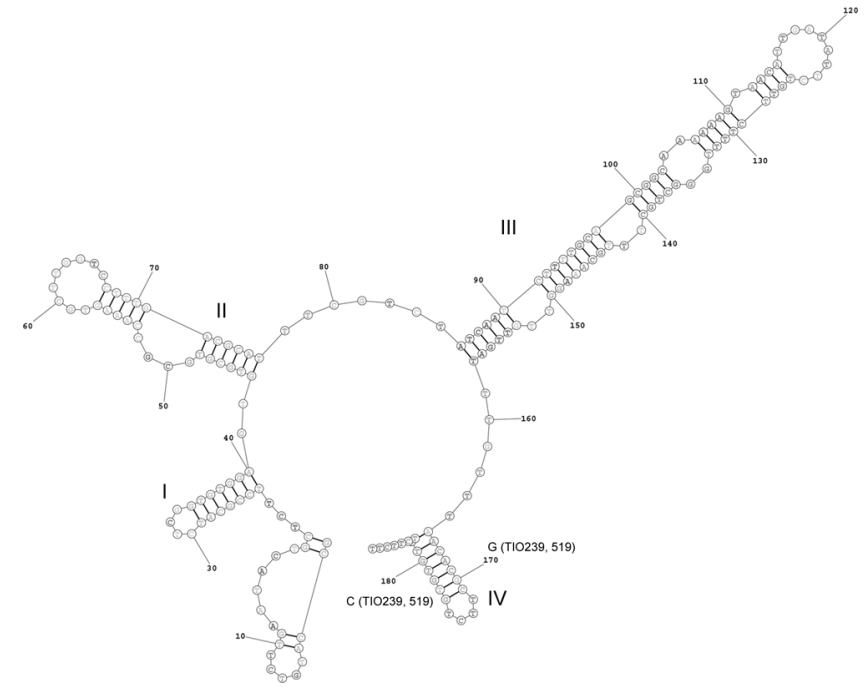

Fig. 2. Predicted secondary structure of strain TIO811 based on ITS-2 rDNA sequences showing four helices (I, II, III and IV) and changes in strains TIO519 and TIO239 (arrows).

column Xbridge BEH C18 $(50 \times 2.1 \mathrm{~mm}, 2.5 \mu \mathrm{m}$, Waters $)$ equipped with a guard column $(5 \times 2.1 \mathrm{~mm}, 2.5 \mu \mathrm{m}$, same stationary phase as column). Water (A) and acetonitrile $90 \%$ (B) both containing $6.7 \mathrm{mM}$ of ammonium hydroxide were used as mobile phases at a flow rate of $400 \mu \mathrm{L} \mathrm{min}^{-1}$. The following gradient was used: $0 \mathrm{~min}, 5 \% \mathrm{~B} ; 1.50 \mathrm{~min}$, $5 \%$ B; $4.5 \mathrm{~min}, 65 \%$ B; $5.00 \mathrm{~min}, 100 \%$ B; $7.00 \mathrm{~min}, 100 \% \mathrm{~B} ; 7.50 \mathrm{~min}$, $5 \% \mathrm{~B} ; 12.00 \mathrm{~min}, 5 \% \mathrm{~B}$. The oven temperature was $30^{\circ} \mathrm{C}$ and the injection volume was $5 \mu \mathrm{L}$. The LC-MS/MS method was used to detect 13 toxins (Table 3). Quantification was performed relative to YTX and homo-YTX standards (National Research Council Canada, NRCC) with a 6-point calibration curve. The limit of quantification was $0.03 \mathrm{ng} \mathrm{mL}^{-1}$ for YTX and homo YTX standards. The ESI interface operated using the following parameters: curtain gas $20 \mathrm{psi}$, temperature: $600^{\circ} \mathrm{C}$, gas 1 $60 \mathrm{psi}$; gas $260 \mathrm{psi}$, ion spray voltage $-4500 \mathrm{~V}$. The dwell time was $20 \mathrm{~ms}$. For detection, parameters were as follows: the declustering potential was $-105 \mathrm{~V}$ and the entrance potential $-10 \mathrm{~V}$. Two collision energies $(-46$ and $-42 \mathrm{eV}$ ) and two collision cell exit potentials ( -9 and $-11 \mathrm{~V}$ ) were applied and the dwell time was $20 \mathrm{~ms}$.

\subsection{Effects of temperature on growth}

Three strains were subjected to growth experiments, representing ribotype A (Weining), ribotype B (TIO519), and ribotype C (TIO853). Experiments on growth at various temperatures $(5,10,15,20,25,30$, and $35^{\circ} \mathrm{C}$ ) were conducted in triplicate using $50 \mathrm{~mL}$ glass bottles with $30 \mathrm{~mL}$ medium and an initial cell density of 5700 cells $\mathrm{mL}^{-1}$. Cultures were acclimated over a period of 15 days to neighboring temperatures successively, at steps no greater than $5{ }^{\circ} \mathrm{C}$ at a time. The light: dark cycle in all experiments was 12:12 h. Subsamples of $0.05 \mathrm{~mL}$ were removed from the culture at 2-day intervals and fixed in Lugol's solution. Each subsample was then transferred to a Sedgwick-Rafter chamber and a minimum of 200 cells per sample were counted. The growth rates in the exponential growth phase were calculated according to the method of Guillard (1973) by a least squares fit of a straight line to the data after logarithmic transformation.

\section{Results}

\subsection{Molecular phylogeny}

All examined $P$. reticulatum strains displayed identical LSU rDNA
(D1-D3) sequences, except one strain (TIO707) from the Mediterranean Sea that showed a transition at one position. The maximum likelihood (ML) and Bayesian inference (BI) analysis based on ITS rDNA sequences yielded similar phylogenetic trees. The ML tree is illustrated in Fig. 1. At least three clades of $P$. reticulatum were identified and referred to as ribotype A, B and C. A sequence of a Swedish strain (GenBank accession number: AB727655) fell outside the group. Ribotype A diverged early with high support (ML bootstrap: 100/BI posterior probability: 0.89) and included strains from the Arctic and temperate areas. Ribotype B included strains from temperate areas with high ML bootstrap support (100) but low BI posterior probability $(<0.7)$. Ribotype C included strains from subtropical and temperate areas with high ML bootstrap support (100) but low BI posterior probability (0.71).

In total, ITS rDNA sequences comparison showed differences at eight positions. Within a single clade, they differed from each other at less than two positions. Genetic distances based on ITS rDNA sequences among the clades ranged from 0.01 to 0.02 (Table 4). The ITS-2 secondary structures of three strains, representing ribotypes $\mathrm{A}, \mathrm{B}$ and $\mathrm{C}$ were predicted. All of them showed four main helix (I-IV). The helix III of strain TIO811 (ribotype A) was two base pairs longer, and the helix II was four base pairs shorter than that of ribotypes B and C. Strain TIO811 displayed one compensatory base changes (CBCs, compensatory change on two sides of a helix pairing) in helix IV (A-T in ribotype A vs G-C in other ribotypes) (Fig. 2). Strain TIO519 (ribotype B) and TIO239 (ribotype C) displayed one hemi-compensatory base changes (hemi-CBCs, compensatory change on only one side of a helix pairing) in helix III (Fig. S2).

\subsection{Morphology}

Cysts of Protoceratium reticulatum were spherical to subspherical and were covered with processes with variable length and capitate distal ends (Fig. 3, Fig. S3, Table 5). The statistical significance of differences in the process length / cyst diameter ratio among three ribotypes was investigated by the $t$-test at the $5 \%$ level. Significant differences were confirmed between ribotype $B$ and the other two ribotypes ( $P<4.3 \%$ ), but not between ribotypes $\mathrm{A}$ and $\mathrm{C}$.

Cysts were observed in clonal cultures of strains 18-760 (ribotype A), TIO440 (ribotype B) and TIO239 (ribotype C). Cysts produced in culture shared similar morphology with those from the field (Fig. 4, Table 5). The statistical significance of differences in the process length - cyst diameter ratio among three ribotypes was investigated by the $t$ test at the 5\% level. Significant differences were confirmed between ribotype $\mathrm{B}$ and the other two ribotypes $(\mathrm{P}<0.01 \%)$, but not between ribotypes $\mathrm{A}$ and $\mathrm{C}$.

Cells of $P$. reticulatum were generally polyhedral and slightly longer than wide. Cells of strain Weining (ribotype A) were 25.4-47.4 $\mu \mathrm{m}$ long (mean $=34.4 \pm 5.7 \mu \mathrm{m}, \quad \mathrm{n}=30$ ) $\quad$ and $20.5-40.7 \mu \mathrm{m}$ wide (mean $=30.5 \pm 4.9 \mu \mathrm{m}, \mathrm{n}=30$ ). The thecae had a rounded epitheca and hypotheca (Fig. 5A). The cingulum was situated in the pre-equatorial part of the cell descending with a displacement of one cingulum width (Fig. 5A). The thecae expressed a plate formula of Po, 3', 1a, 6", $6 \mathrm{C}, 6 \mathrm{~S}, 5^{\prime \prime \prime}, 2^{\prime \prime \prime \prime}$. The plates were more or less reticulated with numerous pores. The pore plate was sigmoidal with a $\lambda$-shaped pore and perforated by $5-9$ pores (Fig. 5B-E). The first apical plate ( $1^{\prime}$ ) was rhombic and had a ventral pore and contacted the anterior sulcal plate (Sa) (Fig. 5B, C). The second and third apical plates $\left(2^{\prime}, 3^{\prime}\right)$ were much larger and irregularly shaped (Fig. 5C). The anterior intercalary plate was fivesided and was variable in position even within the clonal strain, being either separated from or contacting the pore plate (Fig. 5D, E). The precingular series consisted of four four-sided plates $\left(2^{\prime \prime}-5^{\prime \prime}\right)$ and two five-sided plates ( 1 " and 6") (Fig. 5C).

The hypotheca comprised five postcingular plates and two antapical plates. All postcingular plates were trapezoidal and similar in size, although * 2 "' was much smaller (Fig. 5F, G). The first antapical plate 

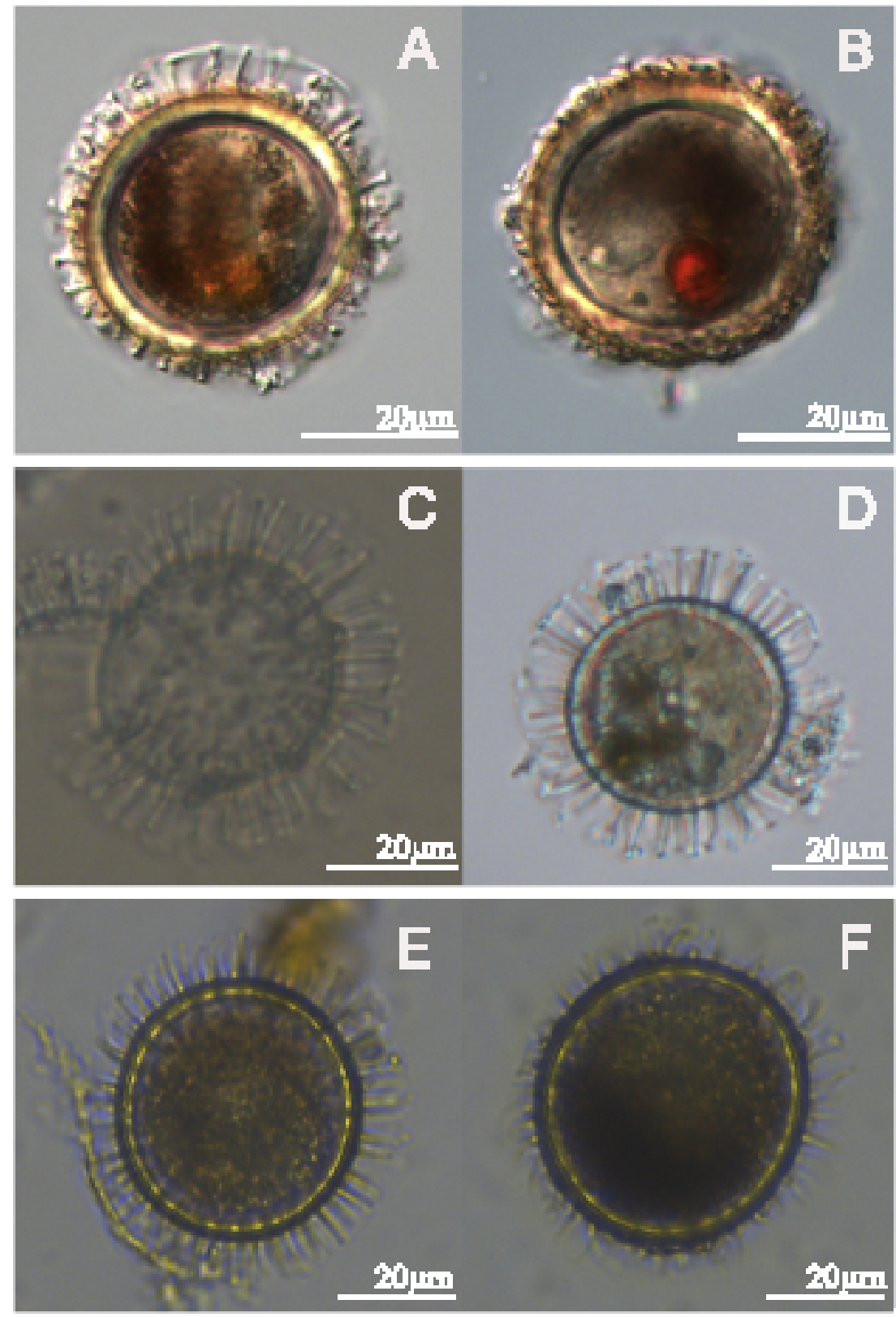

Fig. 3. Light micrographs of cysts of Protoceratium reticulatum from the field.

(A) A living cyst from the Chukchi Sea with short processes of ribotype A. (B) A living cyst from the Chukchi Sea with incomplete processes of ribotype A. (C) An empty cyst from the Saanich Inlet with long processes yielding the strain TIO893 of ribotype B. (D) A living cyst from New Zealand of isolate WN176 of ribotype B. (E) A living cyst from the South China Sea with short processes yielding the strain TIO863 of ribotype C. (F) A living cyst from the South China Sea with short processes yielding the strain TIO864 of ribotype C.

Table 5

Cyst morphology of three ribotypes of Protoceratium reticulatum, including cyst diameter, process length and the ratio of process length and cyst diameter.

\begin{tabular}{|c|c|c|c|c|c|}
\hline Ribotype & Cyst diameter $(\mu \mathrm{m})$ & Process length $(\mu \mathrm{m})$ & Process length/cyst diameter (\%) & Source & $\mathrm{n}$ \\
\hline A & $33.5-44.3($ mean $=38.2 \pm 3.3)$ & $4.1-9.7($ mean $=5.6 \pm 1.3)$ & $10.8-27.1($ mean $=15.0 \pm 4.0)$ & Cysts in the field & 17 \\
\hline B & $33.4-43.5($ mean $=38.1 \pm 3.5)$ & $7.0-9.4($ mean $=8.0 \pm 0.8)$ & $17.9-24.7($ mean $=21.2 \pm 2.3)$ & Cysts in the field & 8 \\
\hline C & $27.8-47.4($ mean $=37.8 \pm 6.8)$ & $4.8-7.6($ mean $=6.5 \pm 1.0)$ & $15.0-22.0($ mean $=17.0 \pm 2.0)$ & Cysts in the field & 8 \\
\hline A & $31.5-35.9($ mean $=33.3 \pm 1.5)$ & $1.8-6.5($ mean $=5.2 \pm 1.4)$ & $5.9-19.2($ mean $=15.6 \pm 3.9)$ & Cysts in culture & 12 \\
\hline B & $35.1-38.0($ mean $=36.7 \pm 1.5)$ & $8.4-9.1($ mean $=8.8 \pm 0.3)$ & $23.0-24.9($ mean $=23.9 \pm 0.8)$ & Cysts in culture & 4 \\
\hline $\mathrm{C}$ & $25.9-39.1($ mean $=33.5 \pm 3.9)$ & $5.0-6.7($ mean $=5.9 \pm 0.7)$ & $15.3-20.7($ mean $=17.7 \pm 1.7)$ & Cysts in culture & 8 \\
\hline
\end{tabular}

( $\left.1^{\prime \prime \prime \prime}\right)$ was small and elongated, located adjacent to plate Sp (Fig. 5G). The second antapical plate $\left(2^{\prime \prime \prime \prime}\right)$ was six-sided and located in the middle of the hypotheca (Fig. 5F).

The sulcus was narrow anteriorly and slightly widens posteriorly. It consisted of six plates. The Sa plate was hook-shaped, and intruded the epitheca to contact plate 1' (Fig. 5B). The anterior left sulcal plate (Ssa) was similar in size with the anterior right sulcal plate (Sda). The left posterior sulcal (Ssp) was larger than the posterior right sulcal (Sdp). 

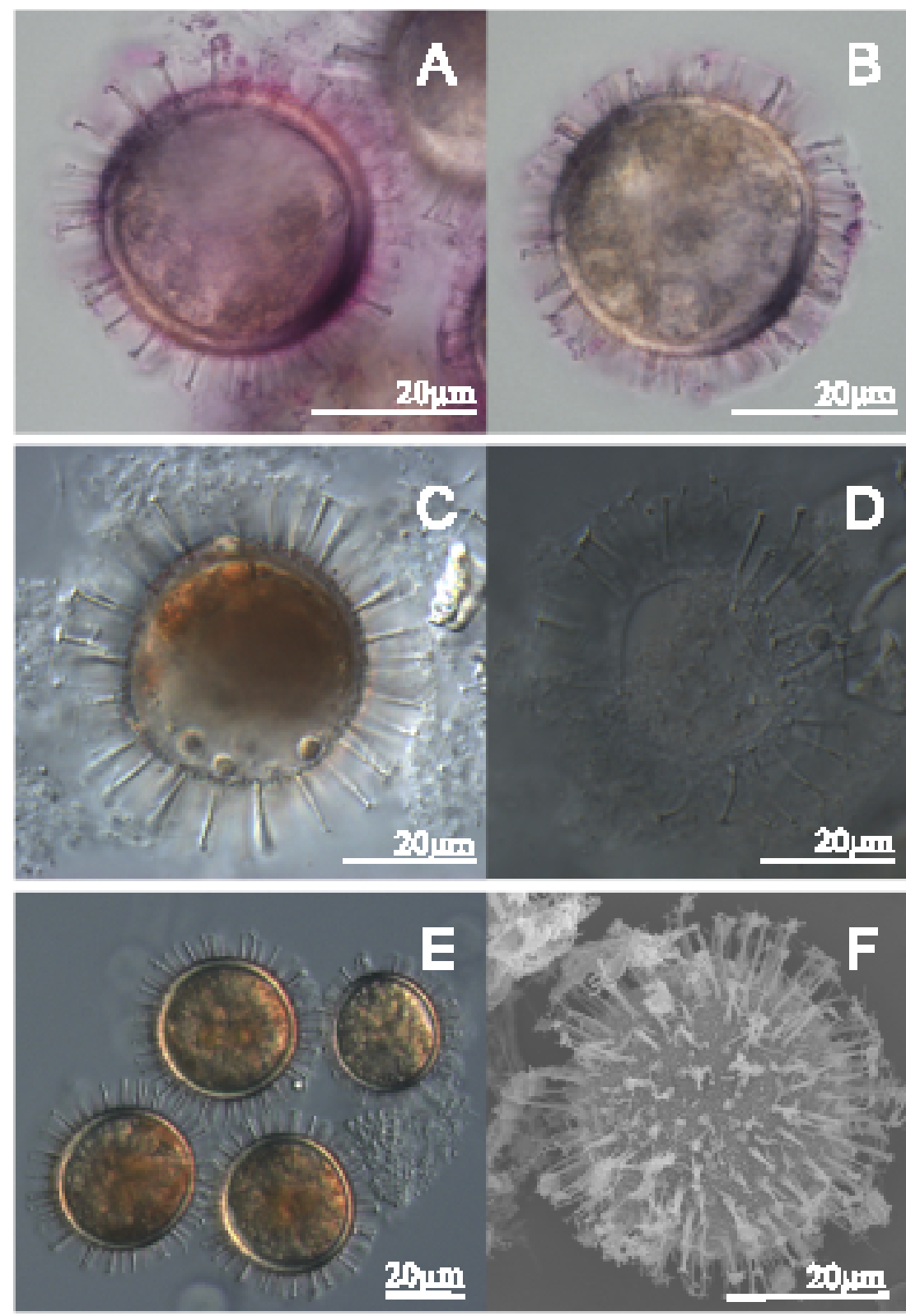

Fig. 4. Light and scanning electron micrographs of cysts of Protoceratium reticulatum in culture.

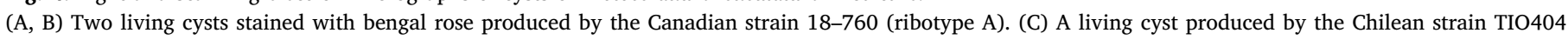

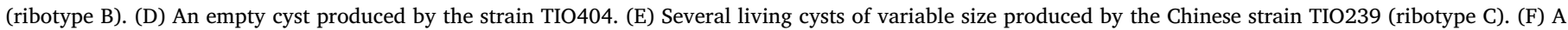
living cyst produced by the strain TIO239.

The large posterior sulcal (Sp) was elongated and much larger than the other sulcal plates (Fig. 5G).

Cells of strain TIO519 (ribotype B) were 23.4-29.0 $\mu \mathrm{m}$ long (mean $=26.2 \pm 1.6 \mu \mathrm{m}, \quad \mathrm{n}=30$ ) $\quad$ and $20.5-27.1 \mu \mathrm{m} \quad$ wide (mean $=23.7 \pm 1.8 \mu \mathrm{m}, \mathrm{n}=30$ ). Cells of strain TIO239 (ribotype C) were $24.2-27.3 \mu \mathrm{m}$ long $($ mean $=25.4 \pm 1.1 \mu \mathrm{m}, \mathrm{n}=10$ ) and $23.0-22.3 \mu \mathrm{m}$ wide (mean $=23.5 \pm 0.9 \mu \mathrm{m}, \mathrm{n}=10$ ). The cell morphology of these two strains was very similar to that of strain Weining, in having similar shapes and ornamentation, and an identical tabulation, including intra-clonal variability in the position of plate 1a (Figs. 6 and 7). Cell size of eleven strains was measured. The average cell length and width were $33.3 \pm 1.6 \mu \mathrm{m}$ and $30.3 \pm 1.4 \mu \mathrm{m}$ (three strains, ribotype A), $29.0 \pm 2.0 \mu \mathrm{m}$ and $26.1 \pm 1.8 \mu \mathrm{m}$ (five strains, ribotype B), and $25.2 \pm 0.5 \mu \mathrm{m}$ and $23.0 \pm 0.5 \mu \mathrm{m}$ (three strains, ribotype C) (Fig. 8). The statistical significance of the differences of cell size among three ribotypes was investigated by the $t$-test at the $1 \%$ level. Significant differences were found among ribotypes $\mathrm{A}, \mathrm{B}$ and $\mathrm{C}$.

\subsection{Growth experiments}

Strain Weining of ribotype A exhibited growth at temperatures between 5 and $20^{\circ} \mathrm{C}$. The highest division rate was 0.45 divisions $\mathrm{d}^{-1}$ at $15^{\circ} \mathrm{C}$, and then growth dropped slowly towards higher and lower temperatures. Strain TIO519 of ribotype B exhibited growth at temperatures between 5 and $25^{\circ} \mathrm{C}$. The highest division rate was around 0.45 divisions $\mathrm{d}^{-1}$ at 20 and $25^{\circ} \mathrm{C}$ and then growth dropped sharply towards lower temperatures. Strain TIO853 of ribotype C exhibited growth at temperatures between 10 and $30{ }^{\circ} \mathrm{C}$. Division rates were similar at temperatures from 20 to $25^{\circ} \mathrm{C}$ (around 0.5 divisions $\mathrm{d}^{-1}$ ) and higher than those at 10 and $15^{\circ} \mathrm{C}\left(<0.3\right.$ divisions $\left.\mathrm{d}^{-1}\right)$ and at $30^{\circ} \mathrm{C}(0.4$ divisions $\mathrm{d}^{-1}$ ) (Fig. 9).

\subsection{Yessotoxins}

All 25 strains of $P$. reticulatum examined produced yessotoxins. Total 

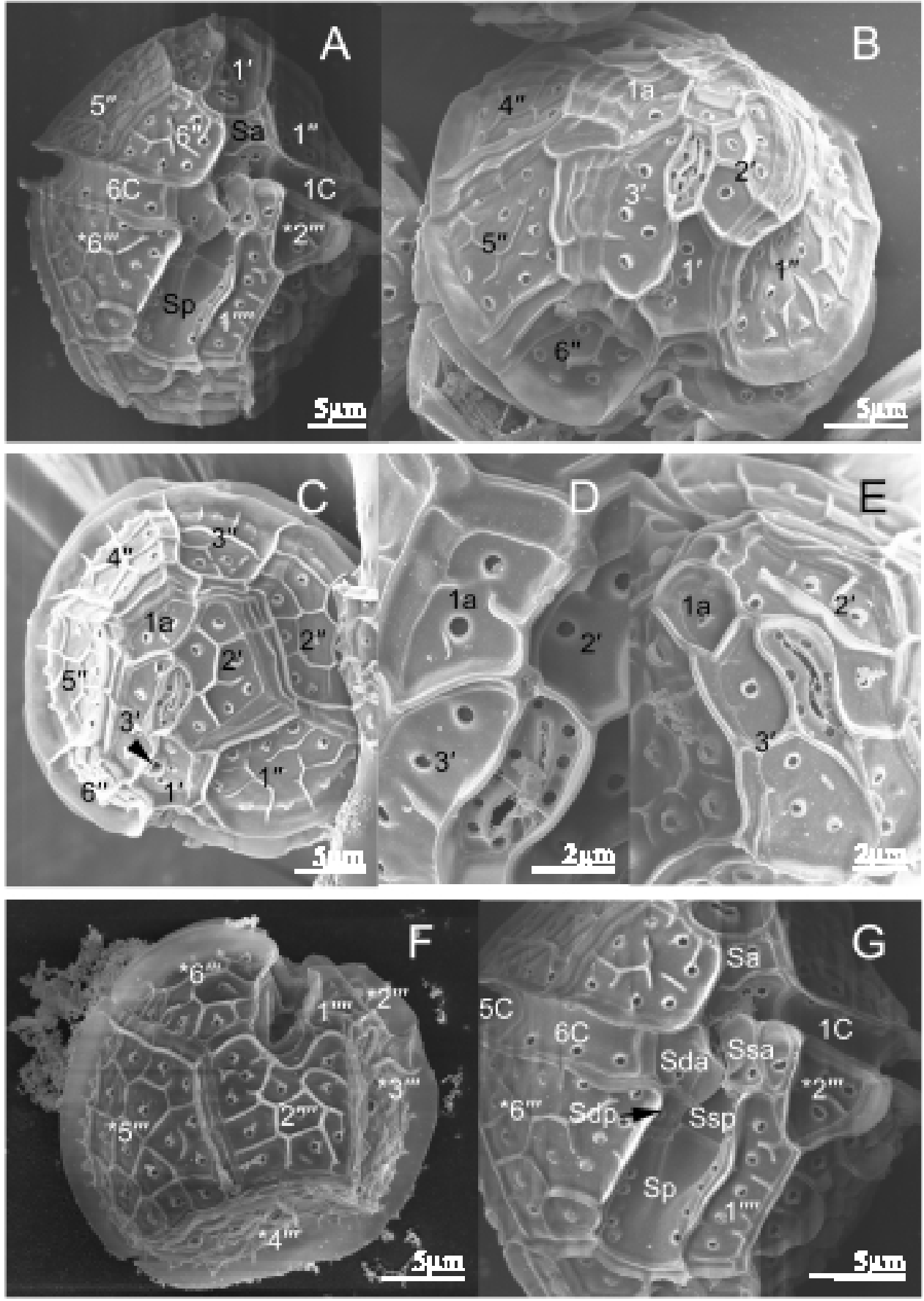

Fig. 5. Scanning electron micrographs of Protoceratium reticulatum strain Weining.

(A). Ventral view showing the first and sixth precingular plates $\left(1^{\prime \prime}, 6^{\prime \prime}\right)$, the second and sixth postcingular plates $\left(* 2^{\prime \prime \prime},{ }^{*} 6^{\prime \prime \prime}\right)$, the first antapical plate $\left(1^{\prime \prime \prime \prime}\right)$ and two cingular plates (1C and 6C).

(B, C). Apical view showing three apical plates $\left(1^{\prime}-3^{\prime}\right)$, one anterior intercalary (1a) plate, six precingular plates $\left(1^{\prime \prime}-6^{\prime \prime}\right)$ and a ventral pore (arrowhead).

(D, E). Apical view showing the connections between the anterior intercalary (1a) plate and the sigmoidal pore plate, which has a $\lambda$-shaped pore and is perforated by pores.

(F). Antapical view showing four postcingular plates $\left(* 2^{\prime \prime \prime}-*^{\prime \prime \prime}\right)$ and the two antapical plates $\left(1^{\prime \prime \prime \prime}, 2^{\prime \prime \prime \prime}\right)$.

(G). The sulcus showing the anterior sulcal plate (Sa), anterior left sulcal plate (Ssa), anterior right sulcal plate (Sda), posterior left sulcal plate (Ssp), posterior right sulcal plate (Sdp) and posterior sulcal plate (Sp). intracellular YTXs range from 0.3-63.2 $\mathrm{pg} \mathrm{cell}^{-1}$. YTXs of ribotype A were dominated by YTX with none homo-YTX. YTXs of ribotype B were also dominated by YTX with none homo-YTX. YTXs of ribotype $C$ were dominated by homo-YTX, but did not produce YTX (Table 6). In addition to YTX and homoYTX, other putative YTX variants were detected at low levels in some strains, but as their unambiguous identification was not possible due to the lack of analytical standards and complete toxin profiles of all strains are beyond the scope of this work, these minor variants are not reported.

\section{Discussion}

\subsection{Cryptic speciation}

ITS rDNA sequences based phylogeny revealed at least three ribotypes of $P$. reticulatum. Secondary structure of ITS2 rDNA sequences in ribotype A shows one $\mathrm{CBC}$ in contrast to the other ribotypes, suggesting that they are unable to cross and thus are different biological species (Coleman, 2009). However, in case of $P$. reticulatum simple cross experiments using cyst formation as a sign of genetic compatibility are not possible since at least ribotypes $\mathrm{B}$ and $\mathrm{C}$ of $P$. reticulatum are homothallic as cysts are produced in clonal cultures.

Cryptic species (or sibling species) are species that are difficult to distinguish based on morphological characters (Mayr and Ashlock, 1991). Designation of strains to the three ribotypes of $P$. reticulatum corresponds to slight size differences in either cysts or cells among strains. Cysts of $P$. reticulatum ribotype B have longer processes (processes/cyst diameter ratio above 20\%) compared to cysts of the other two ribotypes with relatively short processes (processes/cyst diameter ratio less than $17 \%$ ). However, these morphological differences are 

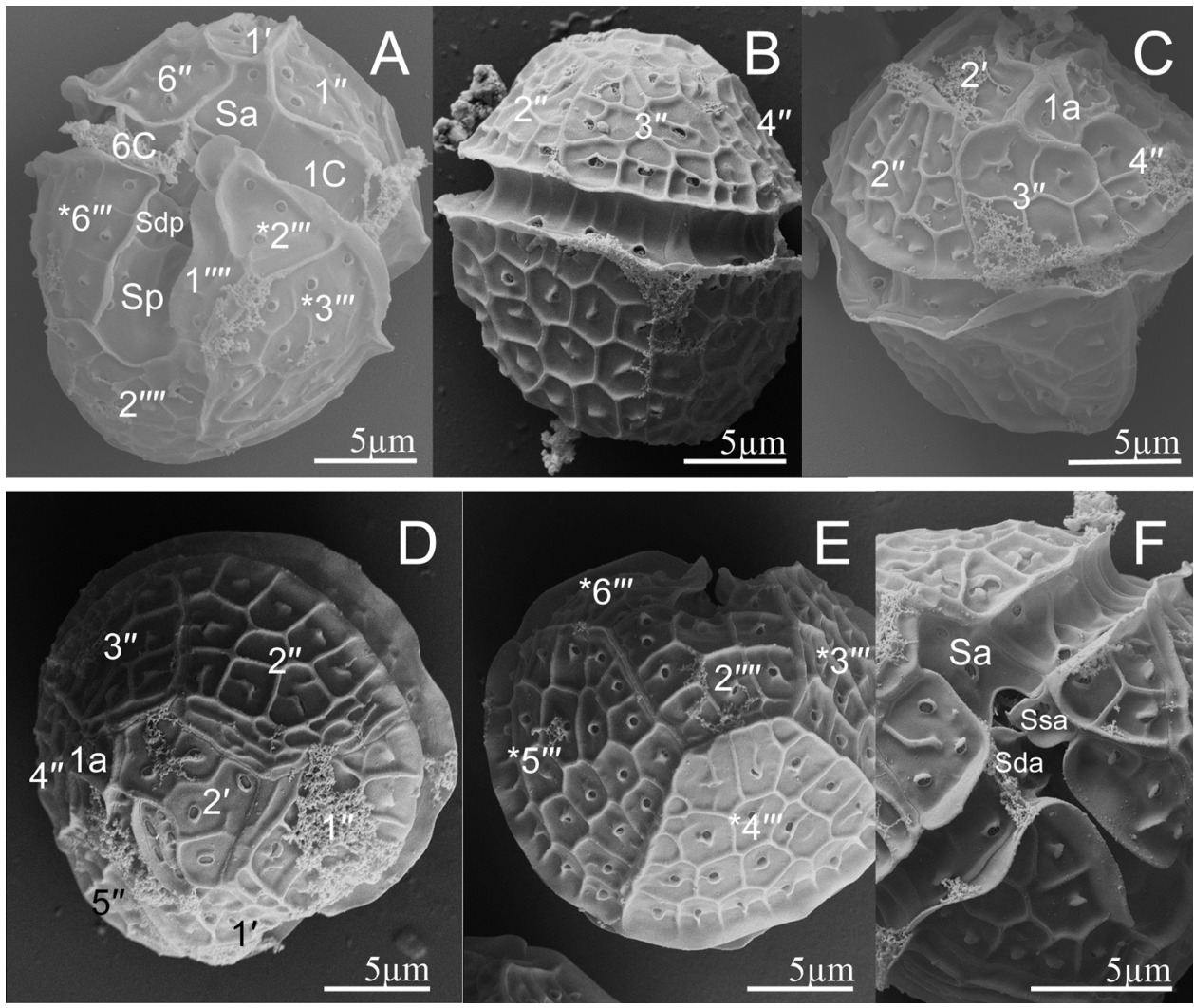

Fig. 6. Scanning electron micrographs of Protoceratium reticulatum strain TIO519.

(A). Ventral view showing the first apical plate $\left(1^{\prime}\right)$, the first, fifth and sixth precingular plates $\left(1^{\prime \prime}, 5^{\prime \prime}, 6^{\prime \prime}\right)$, the second and sixth postcingular plates $\left({ }^{*} 2^{\prime \prime \prime},{ }^{*} 6^{\prime \prime \prime}\right)$, the anterior and posterior sulcal plates (Sa, Sp).

(B). Apical view showing three apical plates $\left(1^{\prime}\right.$ $\left.-3^{\prime}\right)$, six precingular plates $\left(1^{\prime \prime}-6^{\prime \prime}\right)$ and the direct connections between the anterior intercalary (1a) plate and the sigmoidal pore plate. (C). Apical view showing the indirect connections between the anterior intercalary (1a) plate and the sigmoidal pore plate.

(D). Apical view showing six cingular plates (C1-C6).

(E). Antapical view showing five postcingular plates $\left({ }^{\prime \prime \prime \prime}-{ }^{*} 6^{\prime \prime \prime}\right)$ and two antapical plate $\left(1^{\prime \prime \prime \prime}, 2^{\prime \prime \prime \prime}\right)$.

(F). The sulcus showing the anterior left sulcal plate (Ssa), anterior right sulcal plate (Sda), posterior left sulcal plate (Ssp), posterior right sulcal plate (Sdp) and posterior sulcal plate (Sp). small and may be attributed to phenotypic plasticity since average process length of $P$. reticulatum cysts was related to both salinity and temperature at a regional scale (Mertens et al., 2011). It is worth noting that the original cyst yielding strain 18-760 (ribotype A) has long processes $(9.7 \mu \mathrm{m})$ and high process/cyst diameter ratio $(27.1 \%)$, but the culture produced cysts with short processes $(5.2 \pm 1.4 \mu \mathrm{m})$ and low process/cyst diameter ratio $(15.6 \% \pm 3.9 \%)$. Although cell size of $P$. reticulatum differs among the three ribotypes, cell size of specific strains can overlap between ribotypes (Fig. 8). In conclusion, the lack of clear morphological separation between the three ribotypes suggests the presence of cryptic species based on genetic distances estimated from ITS rDNA sequences, and not pseudocryptic species as previously suggested by Mertens et al. (2012a).

Multiple evidence for the presence of cryptic species have been reported in a few dinoflagellates such as Scrippsiella acuminata (Ehrenberg) Kretschmann, Elbrächter, Zinssmeister, S.Soehner, Kirsch, Kusber \& Gottschling and Akashiwo sanguinea (Hirasaka) G. Hansen \& Moestrup (Montresor et al., 2003; Luo et al., 2017). The Alexandrium tamarense species complex comprises several morphologically indistinguishable but genetically differentiated species, which now are even formally designated as five species (John et al., 2014), and this was the first case where dinoflagellate species are defined by sequence differences only. The dinoflagellate $P$. reticulatum shows less genetic distances among ribotypes than the Alexandrium tamarense species complex (0.02 vs 0.2 ) (John et al., 2014). Ribotype A might correspond to the true $P$. reticulatum as one strain from Bergen Fjord (the type locality of $P$. reticulatum) falls within ribotype A. No new species or varieties are established here at the moment, especially considering that limited strains are available from the tropics and southern hemisphere.

\subsection{Biogeography and ecological preference}

The relatively low level of genetic distance between $P$. reticulatum ribotypes compared to species of Alexandrium suggests a recent adaptive radiation to different temperatures. In the early stages of speciation, selection acts largely on physiological, reproductive, or behavioral traits rather than on morphology (Struck et al., 2017), and that may explain the low morphological disparity but differentiated responses to temperature in the three ribotypes of $P$. reticulatum. Such kind of phenomena was also reported in planktonic foraminifers adapting to oligotrophic, mesotrophic or highly productive waters (de Vargas et al., 2002), and in the benthic diatom Navicula phyllepta Kützing showing different tolerance for salinity (Vanelslander et al., 2009).

In contrast to the idea that $P$. reticulatum is a single cosmopolitan species (Zonneveld et al., 2013), the recognition of hidden diversity now allows narrowing the geographic distribution of each ribotype. Ribotype A is distributed in the Arctic and temperate area, thus may be termed as a cold ecotype. This is supported by the fact that a ribotype A strain from Greenland can grow (albeit slowly) even at $1{ }^{\circ} \mathrm{C}$ (Sala-Pérez et al., 2016). Ribotype B appears to have a narrower distribution, is found only in the temperate areas and may be called a moderate ecotype consistent with the fact that they could not survive at $30^{\circ} \mathrm{C}$. Ribotype $\mathrm{C}$ was recorded in the subtropical and temperate areas and may be termed as a warm ecotype, consistent with the fact that they could grow rapidly at $30{ }^{\circ} \mathrm{C}$ (Fig. 9).

Neither ribotype B nor ribotype $\mathrm{C}$ of $P$. reticulatum were recovered in the Arctic where ice cover, prolonged darkness and low water temperature $\left(<10^{\circ} \mathrm{C}\right.$ even in summer (Carmack et al., 1997; Radi et al., 2001)) likely prevent survival and growth of these ribotypes. On the other hand, ribotypes A and B are absent in the subtropical area which support the idea of niche differentiation among these ribotypes. Cysts of $P$. reticulatum have been reported in the tropics (Yap-Dejeto et al., 2018), and the Antarctic (Harland et al., 1999; Harland and Pudsey, 1999; Esper and Zonneveld, 2007), but molecular sequences are not available for these regions yet.

Seasonal and peak occurrence of $P$. reticulatum in the water column has not been well correlated with specific ribotypes so far. Blooms of $P$. reticulatum occurred in later February in Northern Chile when temperatures were from 17 to $25^{\circ} \mathrm{C}$. During this bloom numerous cysts 

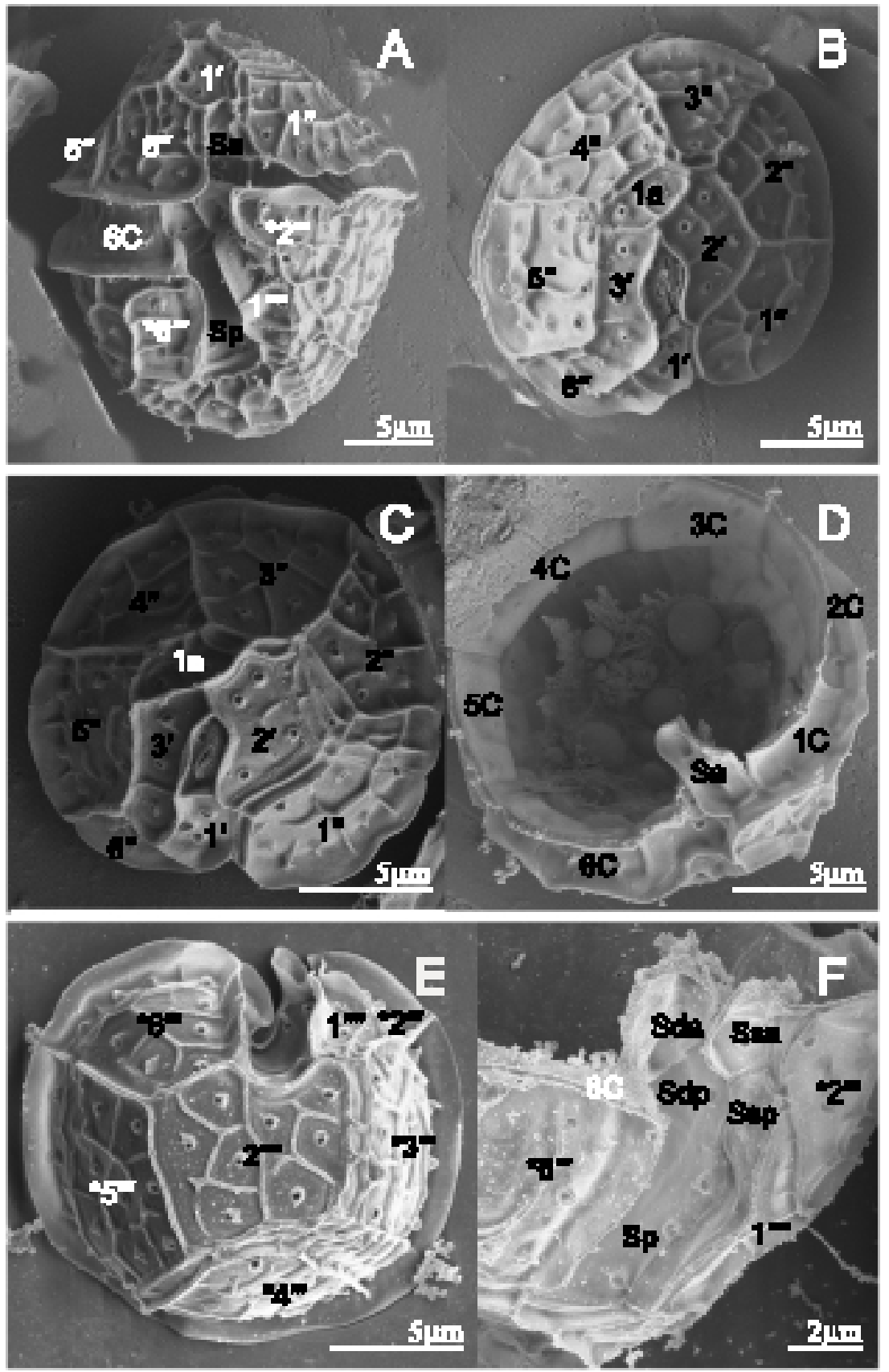

Fig. 7. Scanning electron micrographs of Protoceratium reticulatum strain TIO239.

(A). Ventral view showing the first apical plate (1') with a ventral pore (arrowhead), the first and sixth precingular plates $\left(1^{\prime \prime}, 6^{\prime \prime}\right)$, the second and sixth postcingular plates $\left({ }^{*} 2^{\prime \prime \prime}\right.$, * 6 " $)$, the first antapical plate $\left(1^{\prime \prime \prime \prime}\right)$, two cingular plates $(1 \mathrm{C}$ and $6 \mathrm{C}$ ), posterior right sulcal plate (Sdp) and posterior sulcal plate (Sp).

(B). Dorsal view showing three precingular plates $\left(3^{\prime \prime}-5^{\prime \prime}\right)$. (C). Apical view showing the connections between the anterior intercalary (1a) plate and the sigmoidal pore plate.

(D). Apical view showing three apical plates $\left(1^{\prime}-3^{\prime}\right)$, six precingular plates $\left(1^{\prime \prime}-6^{\prime \prime}\right)$ and the indirect connections between the anterior intercalary (1a) plate and the sigmoidal pore plate.

(E). Antapical view showing four postcingular plates ( ${ }^{\prime \prime \prime \prime}$ $\left.{ }^{*} 6^{\prime \prime \prime}\right)$ and the second antapical plate $\left(2^{\prime \prime \prime \prime}\right)$.

(F). The sulcus showing the anterior sulcal plate (Sa), anterior left sulcal plate (Ssa), and anterior right sulcal plate (Sda). were present in the plankton with process length/diameter ratio of 26.0\% (measured from pictures given in Álvarez et al., 2011) fitting the features of ribotype $\mathrm{B}$. This is also consistent with the finding of optimum growth of ribotype B from 20 to $25^{\circ} \mathrm{C}$. High fluxes of cysts of $P$. reticulatum were found in sediment trap material collected during summer (June and September) from the Gulf of Naples with large process length/diameter ratio $(25.9 \%$, measured from pictures) (Montresor et al., 1998), further support that ribotype B is a warm water ecotype. Information about the seasonal occurrence of ribotypes $\mathrm{A}$ and $\mathrm{C}$, however, is not available.

To date, ribotypes A and $\mathrm{C}$ of $P$. reticulatum were only found in the northern hemisphere. In contrast, ribotype B appears to have a distribution in both northern and southern hemispheres (Fig. S4). Cysts with long processes have been found in Chile by Verleye et al. (2012) for over 144,000 years, thus refute the idea of a recent dispersal of ribotype $B$. It is likely that this ribotype previously had a wider distribution (probably due to cooling of the oceans during ice ages), where both northern and southern hemisphere populations were connected. To summarize, the present results for $P$. reticulatum support that planktonic protists may have a non-random distribution, subjected to both environmental and ecological selection (Whittaker and Rynearson, 2017).

\subsection{Implications for paleoceanographical reconstructions}

The first occurrence of the cyst of $P$. reticulatum is likely in the Miocene of northern Belgium (Louwye and De Schepper, 2010, as Operculodinium centrocarpum sensu Wall and Dale, 1966), however, lack of morphological information prevents it from comparing it to a ribotype. The morphological discrimination of the ribotypes would yield more paleoceanographical information, because each ribotype seems to be related to a different ecological niche. However, cyst morphology of three ribotypes can overlap (Fig. S3), especially process length, as this can be changed by varying salinity and temperature (Mertens et al., 


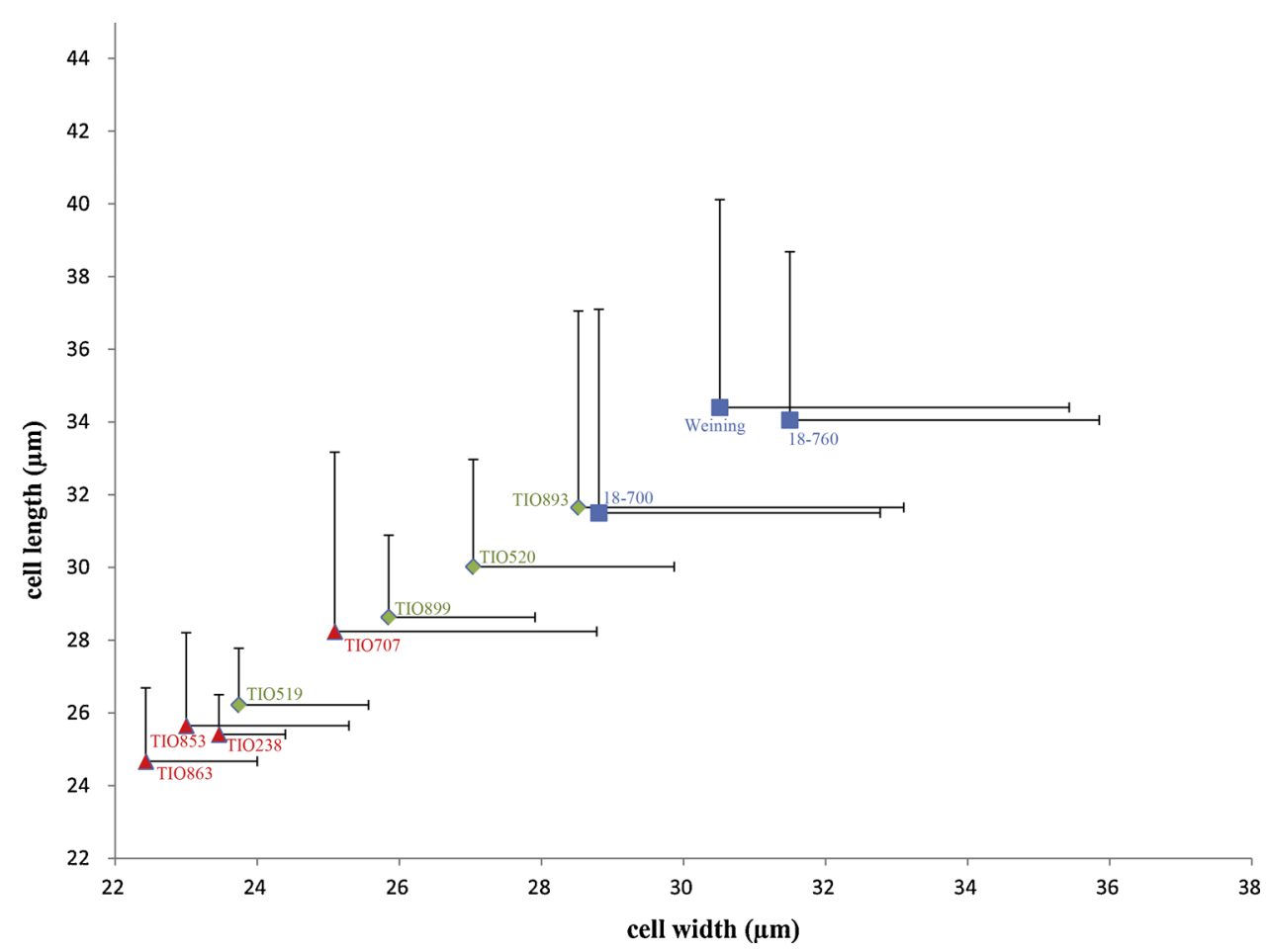

Fig. 8. Length and width $(\bar{x}+s)$ of vegetative cells of the strains used in this study. Strains of ribotype A were indicated in blue; strains of ribotype B were indicated in green and strains of ribotype $\mathrm{C}$ in red.

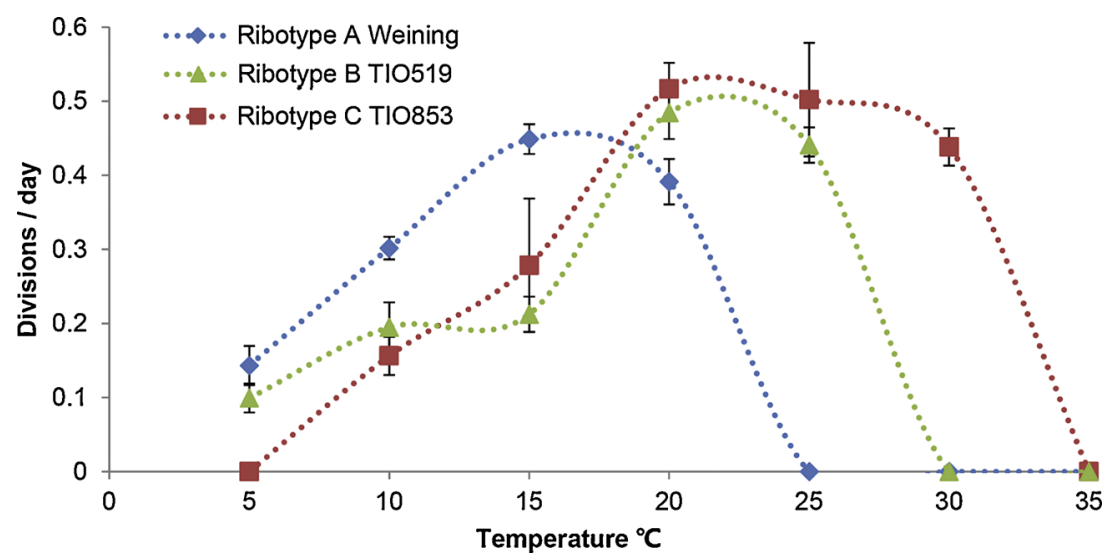

Fig. 9. Growth responses of three strains of Protoceratium reticulatum ribotypes A, B and C under various temperatures.

2011). In addition, in some areas several ribotypes can be present making the reconstructions even more complicated. Ancient sedimentary DNA records of both fossilizing and non-fossilizing protists have been reported with high throughput sequencing (More et al., 2018), thus provide a promising approach to identify ribotypes of $P$. reticulatum unequivocally from the past. The metagenomic approach with ITS rDNA fragment as a target can be helpful in paleoceanographical reconstruction, where ribotype A of $P$. reticulatum (as Operculodinium centrocarpum var. cezare) might be related with the duration of ice cover (Radi and de Vernal, 2008).

\subsection{Yessotoxins}

The presented results support that there are at least two types of $P$. reticulatum, the YTX producers and the homoYTX producers (Paz et al., 2007). The new strains presented here are able to produce yessotoxins from $0.3-63.2 \mathrm{pg}$ cell $^{-1}$, supporting the notion that the production of yessotoxins by $P$. reticulatum differs among strains (Satake et al., 1999). Absence of YTX and dominance of homoYTX in strains of ribotype C may differentiate it from ribotypes $\mathrm{A}$ and $\mathrm{B}$, which produce predominantly YTX. Three strains VGO757, VGO758 and GG1AM from the Mediterranean Sea were reported to produce predominantly YTX, too (representing between $92.7 \%$ and $97.6 \%$ of total toxin) (Paz et al., 2007). These three strains were identified as ribotype B here (Fig. 1), supporting that toxin profiles are constant within a single ribotype. Such kind of metabolic differences mirror the morphological and genetic distinction among ribotypes. HomoYTX produced by Gonyaulax membranacea was found to be responsible for massive mortality of abalone in South Africa (Pitcher et al., 2019), and this underlines the potential risk of ribotype $C$. reticulatum of presence of ribotype $C$ in the East China Sea where abalone farms are abundant.

\section{Acknowledgements}

This project was supported by the National Key Research and Development of China (2017YFC1404303) and National Natural Science Foundation of China (41676117). Funding was also provided to KNM, AD and GB by a "Projet de politique de site" (MINITOX). Partial 
Table 6

Yield and major YTXs contents of three ribotypes of Protoceratium reticulatum and their locations (nd: not detected).

\begin{tabular}{|c|c|c|c|c|c|}
\hline Strains/isolates & Ribotype & Location & Total YTXs (pg cell ${ }^{-1}$ ) & $\begin{array}{l}\text { YTX } \\
\left(\mathrm{pg} \mathrm{cell}^{-1}\right)\end{array}$ & HomoYTX (pg cell ${ }^{-1}$ ) \\
\hline TIO821 & A & Chukchi Sea & 18.0 & 18.0 & nd \\
\hline TIO829 & A & Chukchi Sea & 6.9 & 6.9 & nd \\
\hline Weining & A & Dalian, Yellow Sea & 5.6 & 4.4 & nd \\
\hline MP-B06 & NA & Disko Bay, Greenland & 5.3 & 5.2 & nd \\
\hline MP-D11 & NA & Godhabsfjord, Greenland & 16.8 & 15.2 & nd \\
\hline MP-F05 & A & Godhabsfjord, Greenland & 9.6 & 9.0 & nd \\
\hline MP-F06 & $\mathrm{A}$ & Godhabsfjord, Greenland & 4.0 & 3.9 & nd \\
\hline MP-S-D1 & A & Disko Bay, Greenland & 15.6 & 15.2 & nd \\
\hline MP-S-F7 & NA & Disko Bay, Greenland & 15.0 & 14.4 & nd \\
\hline PR2 & A & Greenland, Southern Tip & 26.1 & 22.2 & nd \\
\hline PR3 & $\mathrm{A}$ & Disko Bay, Greenland & 24.4 & 21.3 & nd \\
\hline PR4 & A & Disko Bay, Greenland & 31.4 & 23.6 & nd \\
\hline $18-760$ & A & Saint-Pierre et Miquelon, Canada & 63.2 & 63.2 & nd \\
\hline $18-700$ & $\mathrm{~A}$ & Oak Bay, BC, Canada & 47.2 & 47.2 & nd \\
\hline TIO893 & B & Saanich Inlet, Canada & 5.6 & 4.7 & nd \\
\hline TIO440 & $\mathrm{B}$ & Comau Fjord, Chile & 1.0 & 1.0 & nd \\
\hline TIO519 & B & Oyster Bay, New Zealand & 0.3 & 0.2 & nd \\
\hline TIO707 & $\mathrm{C}$ & Corsica, France & 1.0 & nd & 1.0 \\
\hline TIO831 & $\mathrm{C}$ & Dalian, Yellow Sea, China & 14.4 & nd & 12.9 \\
\hline TIO853 & $\mathrm{C}$ & Dalian, Yellow Sea, China & 8.6 & nd & 8.4 \\
\hline TIO238 & NA & East China Sea, China & 1.9 & nd & 1.5 \\
\hline TIO239 & $\mathrm{C}$ & East China Sea, China & 9.1 & nd & 8.9 \\
\hline TIO240 & NA & East China Sea, China & 0.3 & nd & 0.3 \\
\hline TIO269 & $\mathrm{C}$ & East China Sea, China & 13.2 & nd & 12.8 \\
\hline TIO863 & $\mathrm{C}$ & South China Sea, China & 5.0 & nd & 4.8 \\
\hline
\end{tabular}

funding for this research was provided by a Natural Sciences and Engineering Research Council of Canada (NSERC) Discovery grant to VP. Herlé Goraguer is thanked for providing a sediment sample from Saint-Pierre-et-Miquelon. Yoann Baldi is thanked for sampling Diane Lagoon (Corsica). Francine Beaujot is thanked for collecting Chilean sample from Comau Fjord (Piedra C). Kenneth Mertens, Gwenael Bilien and Stijn De Schepper acknowledge a PHC AURORA Grant (38497RE). [CG]

\section{Appendix A. Supplementary data}

Supplementary material related to this article can be found, in the online version, at doi:https://doi.org/10.1016/j.hal.2019.05.003.

\section{References}

Aasen, J., Samdal, I.A., Miles, C.O., Dahl, E., Briggs, L.R., Aune, T., 2005. Yessotoxins in Norwegian blue mussels (Mytilus edulis): uptake from Protoceratium reticulatum, metabolism and depuration. Toxicon 45 (3), 265-272.

Adachi, M., Sako, Y., Ishida, Y., 1996. Analysis of Alexandrium (Dinophyceae) species using sequences of the $5.8 \mathrm{~S}$ ribosomal DNA and internal transcribed spacer regions. J. Phycol. 32 (3), 424-432.

Akselman, R., Krock, B., Alpermann, T.J., Tillmann, U., Borel, C.M., Almandoz, G.O., Ferrario, M.E., 2015. Protoceratium reticulatum (Dinophyceae) in the austral Southwestern Atlantic and the first report on YTX-production in shelf waters of Argentina. Harmful Algae 45, 40-52.

Al Muftah, A., Selwood, A.I., Foss, A.J., Al-Jabri, H.M.S.J., Potts, M., Yilmaz, M., 2016. Algal toxins and producers in the marine waters of Qatar, Arabian Gulf. Toxicon 122, 54-66.

Álvarez, G., Uribe, E., Díaz, R., Braun, M., Mariño, C., Blanco, J., 2011. Bloom of the Yessotoxin producing dinoflagellate Protoceratium reticulatum (Dinophyceae) in Northern Chile. J. Sea Res. 65 (4), 427-434.

Álvarez, G., Uribe, E., Regueiro, J., Blanco, J., Fraga, S., 2016. Gonyaulax taylorii, a new yessotoxins-producer dinoflagellate species from Chilean waters. Harmful Algae 58, $8-15$.

Balech, E., 1980. On the thecal morphology of dinoflagellates with special emphasis on circular and sulcal plates Anales del Centro de Ciencias del Mar y Limnologia 7. Universidad Nacional Autonomia de Mexico, pp. 57-68.

Balech, E., 1988. Los dinoflagellados del Atlantico sudoccidental. Publicaciones Especiales Instituto Español de Oceanografia.

Boc, A., Diallo, A.B., Makarenkov, V., 2012. T-REX: a web server for inferring, validating and visualizing phylogenetic trees and networks. Nucleic Acids Res. 40 (W1), W573-W579.

Braarud, T., 1945. Morphological observations on marine dinoflagellate cultures (Porella perforata, Goniaulax tamarensis, Protoceratium reticulatum). Avh. Norske Videnskakad.
Oslo 11 (11), 1-18.

Braarud, T., Føyn Hofsvang, B., Hjelmfoss, P., Överland, A.-K., 1974. The natural history of the hardangerfjord: 10 . The phytoplankton in 1955-56. The quantitative phytoplankton cycle in the fjord waters and in the offshore coastal waters. Sarsia 55 (1), 63-98.

Carmack, E.C., Aagaard, K., Swift, J.H., MacDonald, R.W., McLaughlin, F.A., Jones, E.P., Perkin, R.G., Smith, J.N., Ellis, K.M., Killius, L.R., 1997. Changes in temperature and tracer distributions within the Arctic Ocean: results from the 1994 Arctic Ocean section. Deep-Sea Res. Pt. II 44 (8), 1487-1502.

Cassis, D., 2005. The Effect of Harmful Algae on the Summer Mortality of Juvenile Pacific Oysters (Crassostrea Gigas). Unpublished MSc thesis. University of British Columbia, pp. 73.

Ciminiello, P., Fattorusso, E., Forino, M., Magno, S., Poletti, R., Satake, M., Viviani, R., Yasumoto, T., 1997. Yessotoxin in mussels of the northern Adriatic Sea. Toxicon 35, 177-183.

Ciminiello, P., Fattorusso, E., Forino, M., Magno, S., Poletti, R., Viviani, R., 1998. Isolation of adriatoxin, a new analogue of yessotoxin from mussels of the Adriatic sea. Tetrahedron Lett. 39 (48), 8897-8900.

Ciminiello, P., Dell'Aversano, C., Fattorusso, E., Forino, M., Magno, S., Poletti, R., 2002. Direct detection of yessotoxin and its analogues by liquid chromatography coupled with electrospray ion trap mass spectrometry. J. Chromatogr. 968 (4), 61-69.

Coleman, A.W., 2009. Is there a molecular key to the level of "biological species" in eukaryotes? A DNA guide. Mol. Phylogenet. Evol. 50 (1), 197-203.

Daugbjerg, N., Hansen, G., Larsen, J., Moestrup, Ø., 2000. Phylogeny of some of the major genera of dinoflagellates based on ultrastructure and partial LSU rDNA sequence data, including the erection of three new genera of unarmoured dinoflagellates. Phycologia 39 (4), 302-317.

de Vargas, C., Bonzon, M., Rees, N.W., Pawlowski, J., Zaninetti, L., 2002. A molecular approach to biodiversity and biogeography in the planktonic foraminifer Globigerinella siphonifera (d'Orbigny). Mar. Micropaleontol. 45 (2), 101-116.

de Vernal, A., Mudie, P., 1989. Pliocene and Pleistocene palynostratigraphy at ODP sites 646 and 647, eastern and southern Labrador Sea. Proceedings of the Ocean Drilling Program, Scientific Results, Ocean Drilling Program College Station, Texas.

de Vernal, A., Henry, M., Matthiessen, J., Mudie, P.J., Rochon, A., Boessenkool, K.P., Eynaud, F., Grøsfjeld, K., Guiot, J., Hamel, D., 2001. Dinoflagellate cyst assemblages as tracers of sea-surface conditions in the northern North Atlantic, Arctic and subArctic seas: the new ' $n=677$ 'data base and its application for quantitative palaeoceanographic reconstruction. J. Quat. Sci. 16 (7), 681-698.

De Wit, P., Rogers-Bennett, L., Kudela, R.M., Palumbi, S.R., 2014. Forensic genomics as a novel tool for identifying the causes of mass mortality events. Nat. Commun. 5, 3652.

Dodge, J., 1989. Some revisions of the family Gonyaulacaceae (Dinophyceae) based on a scanning electron microscope study. Bot. Mar. 32 (4), 275-298.

Domínguez, H.J., Souto, M.L., Norte, M., Daranas, A.H., Fernández, J.J., 2010. Adriatoxin-B, the first C-13 terminal truncated YTX analogue obtained from dinoflagellates. Toxicon 55 (8), 1484-1490.

Esper, O., Zonneveld, K.A., 2007. The potential of organic-walled dinoflagellate cysts for the reconstruction of past sea-surface conditions in the Southern Ocean. Mar. Micropaleontol. 65 (3), 185-212.

Fensome, R.A., Taylor, F.J.R., Norris, G., Sarjeant, W.A.S., Wharton, D.I., Williams, G.L., 1993. A classification of fossil and living dinoflagellates. Micropaleontol. Special 
Publ. 7, 1-245.

Grindley, J., Nel, E., 1968. Mussel poisoning and shellfish mortality on the West Coast of Africa. S. Afr. J. Sci. 64, 420-422.

Guillard, R.R.L., 1973. Division rates. In: Stein, J.R. (Ed.), Handbook of Phycological Methods. Culture Methods and Growth Measurements. Cambridge University Press, Cambridge, New York, pp. 289-311.

Guillard, R.R.L., Ryther, J.H., 1962. Studies of marine planktonic diatoms. I. Cyclotella nana Hustedt and Detonula confervacea Cleve. Can. J. Microbiol. 8, 229-239.

Hall, T.A., 1999. BioEdit: A User-friendly Biological Sequence Alignment Editor and Analysis Program for Windows 95/98/NT. pp. 95-98.

Harland, R., Pudsey, C.J., 1999. Dinoflagellate cysts from sediment traps deployed in the Bellingshausen, Weddell and Scotia seas, Antarctica. Mar. Micropaleontol. 37 (2), 77-99.

Harland, R., FitzPatrick, M.E., Pudsey, C.J., 1999. Latest Quatrnary dinoflagellate cyst climatostratigraphy for three cores from the Falkland Trough, Scotia and Weddell seas, Southern Ocean. Rev. Palaeobot. Palynol. 107 (3-4), 265-281.

Head, M.J., 2007. Last Interglacial (Eemian) hydrographic conditions in the southwestern Baltic Sea based on dinoflagellate cysts from Ristinge Klint, Denmark. Geol. Mag. 144 (06), 987-1013.

Hernández-Becerril, D.U., Rodríguez-Palacio, M.C., Lozano-Ramírez, C., 2010. Morphology of two bloom-forming or potentially toxic marine dinoflagellates from the Mexican Pacific, Heterocapsa pygmaea and Protoceratium reticulatum (Dinophyceae). Cryptogam. Algol. 31 (2), 245-254.

Howard, M.D.A., Silver, M., Kudela, R.M., 2008. Yessotoxin detected in mussel (Mytilus californicus) and phytoplankton samples from the U.S. west coast. Harmful Algae 7 (5), 646-652.

Howard, M.D.A., Smith, G.J., Kudela, R.M., 2009. Phylogenetic relationships of yessotoxin-producing dinoflagellates, based on the large subunit and internal transcribed spacer ribosomal DNA domains. Appl. Environ. Microb. 75 (1), 54-63.

Jansson, I.-M., Mertens, K.N., Head, M.J., de Vernal, A., Londeix, L., Marret, F. Matthiessen, J., Sangiorgi, F., 2014. Statistically assessing the correlation between salinity and morphology in cysts produced by the dinoflagellate Protoceratium reticulatum from surface sediments of the North Atlantic Ocean,

Mediterranean-Marmara-Black Sea region, and Baltic-Kattegat-Skagerrak estuarine system. Palaeogeogr. Palaeoclimatol. Palaeoecol. 399, 202-213.

John, U., Litaker, R.W., Montresor, M., Murray, S., Brosnahan, M.L., Anderson, D.M., 2014. Formal revision of the Alexandrium tamarense species complex (Dinophyceae) taxonomy: the introduction of five species with emphasis on molecular-based (rDNA) classification. Protist 165 (6), 779-804.

Katoh, K., Standley, D.M., 2013. MAFFT multiple sequence alignment software version 7: improvements in performance and usability. Mol. Biol. Evol. 30 (4), 772-780.

Keller, A., Schleicher, T., Schultz, J., Müller, T., Dandekar, T., Wolf, M., 2009. 5.8 S-28S rRNA interaction and HMM-based ITS2 annotation. Gene 430 (1-2), 50-57.

Koike, K., Horie, Y., Suzuki, T., Kobiyama, A., Kurihara, K., Takagi, K., Kaga, S.-N., Oshima, Y., 2006. Protoceratium reticulatum in northern Japan: environmental factors associated with seasonal occurrence and related contamination of yessotoxin in scallops. J. Plankton Res. 28 (1), 103-112.

Lee, J.S., Tangen, K., Darhl, E., Hovgaard, P., Yasumoto, T., 1988. Diarrhetic shellfish toxins in Norwegian mussels. Nippon. Suisan Gakkaishi 54, 1953-1957.

Li, A., Ma, J., Cao, J., McCarron, P., 2012. Toxins in mussels (Mytilus galloprovincialis) associated with diarrhetic shellfish poisoning episodes in China. Toxicon 60 (3), 420-425.

Li, A., Chen, H., Qiu, J., Lin, H., Gu, H., 2015. Determination of multiple toxins in whelk and clam samples collected from the Chukchi and Bering seas. Toxicon 109, 84-93.

Liu, L., Wei, N., Gou, Y., Li, D., Liang, Y., Xu, D., Liu, R., Sui, S., Jiang, T., 2017. Seasonal variability of Protoceratium reticulatum and yessotoxins in Japanese scallop Patinopecten yessoensis in northern Yellow Sea of China. Toxicon 139, 31-40.

Louwye, S., De Schepper, S., 2010. The Miocene-Pliocene hiatus in the southern North Sea Basin (northern Belgium) revealed by dinoflagellate cysts. Geol. Mag. 147 (5), 760-776.

Luo, Z., Yang, W., Leaw, C.P., Pospelova, V., Bilien, G., Liow, G.R., Lim, P.T., Gu, H., 2017. Cryptic diversity within the harmful dinoflagellate Akashiwo sanguinea in coastal Chinese waters is related to differentiated ecological niches. Harmful Algae 66, 88-96.

MacKenzie, L., Holland, P., McNabb, P., Beuzenberg, V., Selwood, A., Suzuki, T., 2002 Complex toxin profiles in phytoplankton and Greenshell mussels (Perna canaliculus), revealed by LC-MS/MS analysis. Toxicon 40 (9), 1321-1330.

Madhav, V.G., Kondalarao, B., 2004. Distribution of phytoplankton in the coastal waters of east coast of India. Indian J. Mar. Sci. 33 (3), 262-268.

Martiny, A.C., Tai, A.P., Veneziano, D., Primeau, F., Chisholm, S.W., 2009. Taxonomic resolution, ecotypes and the biogeography of Prochlorococcus. Environ. Microbiol. 11 (4), 823-832.

Matsuoka, K., McMinn, A., Wrenn, J.H., 1997. Restudy of the holotype of Operculodinium centrocarpum (Deflandre \& Cookson) Wall (Dinophyceae) from the Miocene of Australia, and the taxonomy of related species. Palynology 21 (1), 19-33.

Mayr, E., Ashlock, P., 1991. Principles of Systematic Zoology. MacGraw Hill, New York. Mertens, K.N., Dale, B., Ellegaard, M., Jansson, I., Godhe, A., Kremp, A., Louwye, S., 2011. Process length variation in cysts of the dinoflagellate Protoceratium reticulatum, from surface sediments of the Baltic-kattegat-skagerrak estuarine system: a regional salinity proxy. Boreas 40 (2), 242-255.

Mertens, K.N., Bringué, M., Van Nieuwenhove, N., Takano, Y., Pospelova, V., Rochon, A., de Vernal, A., Radi, T., Dale, B., Patterson, R.T., Weckström, K., Andrén, E., Louwye, S., Matsuoka, K., 2012a. Process length variation of the cyst of the dinoflagellate Protoceratium reticulatum in the North Pacific and Baltic-Skagerrak region: calibration as an annual density proxy and first evidence of pseudo-cryptic speciation. J. Quat. Sci. 27 (7), 734-744.
Mertens, K.N., Bradley, L.R., Takano, Y., Mudie, P.J., Marret, F., Aksu, A.E., Hiscott, R.N., Verleye, T.J., Mousing, E.A., Smyrnova, L.L., Bagheri, S., Mansor, M., Pospelova, V., Matsuoka, K., 2012b. Quantitative estimation of Holocene surface salinity variation in the Black Sea using dinoflagellate cyst process length. Quat. Sci. Rev. 39, 45-59. Mertens, K.N., Carbonell-Moore, M.C., Pospelova, V., Head, M.J., Highfield, A., Schroeder, D., Gu, H., Andree, K.B., Fernández, M., Yamaguchi, A., Takano, Y. Matsuoka, K., Nézan, E., Bilien, G., Okolodkov, Y., Koike, K., Hoppenrath, M., Pfaff, M., Pitcher, G., Al-Muftah, A., Rochon, A., Lim, P.T., Leaw, C.P., Lim, Z.F., Ellegaard, M., 2018a. Pentaplacodinium saltonense gen. et sp. nov. (Dinophyceae) and its relationship to the cyst-defined genusOperculodinium and yessotoxin-producing Protoceratium reticulatum. Harmful Algae 71, 57-77.

Mertens K.N., Carbonell-Moore M.C., Pospelova V., Head M.J. 2018b. Ceratocorys mariaovidiorum P.Salgado, S.Fraga, F.Rodríguez, P.Riobó \& I.Bravo is a junior synonym of Pentaplacodinium saltonense K.N.Mertens, M.C.Carbonell-Moore, V.Pospelova \& M.J. Head. Notulae algarum.

Miles, C.O., Samdal, I.A., Aasen, J.A.B., Jensen, D.J., Quilliam, M.A., Petersen, D., Briggs, L.M., Wilkins, A.L., Rise, F., Cooney, J.M., MacKenzie, A.L., 2005a. Evidence for numerous analogs of yessotoxin in Protoceratium reticulatum. Harmful Algae 4 (6), 1075-1091.

Miles, C.O., Wilkins, A.L., Hawkes, A.D., Selwood, A.I., Jensen, D.J., Munday, R., Cooney, J.M., Beuzenberg, V., 2005b. Polyhydroxylated amide analogs of yessotoxin from Protoceratium reticulatum. Toxicon 45 (1), 61-71.

Montresor, M., Zingone, A., Sarno, D., 1998. Dinoflagellate cyst production at a coastal Mediterranean site. J. Plankton Res. 20 (12), 2291-2312.

Montresor, M., Sgrosso, S., Procaccini, G., Kooistra, W.H.C.F., 2003. Intraspecific diversity in Scrippsiella trochoidea (Dinopbyceae): evidence for cryptic species. Phycologia 42 (1), 56-70.

More, K.D., Orsi, W.D., Galy, V., Giosan, L., He, L., Grice, K., Coolen, M.J.L., 2018. A 43 kyr record of protist communities and their response to oxygen minimum zone variability in the Northeastern Arabian Sea. Earth Planet. Sci. Lett. 496, 248-256.

Morton, S.L., Vershinin, A., Leighfield, T., Smith, L., Quilliam, M., 2007. Identification of yessotoxin in mussels from the Caucasian Black Sea Coast of the russian federation. Toxicon 50 (4), 581-584.

Murata, M., Kumagai, M., Lee, J.S., Yasumoto, T., 1987. Isolation and structure of yessotoxin, a novel polyether compound implicated in diarrhetic shellfish poisoning. Tetrahedron Lett. 28 (47), 5869-5872.

Paez-Reyes, M., Head, M.J., 2013. The cenozoic Gonyaulacacean dinoflagellate generaOperculodinium Wall, 1967 and Protoceratium Bergh, 1881 and their phylogenetic relationships. J. Paleontol. 87 (5), 786-803.

Paz, B., Riobó, P., Fernández, M.L., Fraga, S., Franco, J.M., 2004. Production and release of yessotoxins by the dinoflagellates Protoceratium reticulatum and Lingulodinium polyedrum in culture. Toxicon 44 (3), 251-258.

Paz, B., Riobó, P., Ramilo, I., Franco, J.M., 2007. Yessotoxins profile in strains of Protoceratium reticulatum from Spain and USA. Toxicon 50 (1), 1-17.

Pitcher, G.C., Foord, C.J., Macey, B.M., Mansfield, L., Mouton, A., Smith, M.E., Osmond, S.J., van der Molen, L., 2019. Devastating farmed abalone mortalities attributed to yessotoxin-producing dinoflagellates. Harmful Algae 81, 30-41.

Posada, D., 2008. jModelTest: phylogenetic model averaging. Mol. Biol. Evol. 25 (7), 1253-1256.

Radi, T., de Vernal, A., 2008. Dinocysts as proxy of primary productivity in mid-high latitudes of the Northern Hemisphere. Mar. Micropaleontol. 68 (1), 84-114.

Radi, T., de Vernal, A., Peyron, O., 2001. Relationships between dinoflagellate cyst assemblages in surface sediment and hydrographic conditions in the Bering and Chukchi seas. J. Quat. Sci. 16 (7), 667-680.

Reinecke, P., 1967. Gonyaulax grindleyi sp. nov.: a dinoflagellate causing a red tide at Elands Bay, Cape Province, in December 1966. S. Afr. J. Bot. 33, 157-160.

Riccardi, M., Guerrini, F., Roncarati, F., Milandri, A., Cangini, M., Pigozzi, S., Riccardi, E., Ceredi, A., Ciminiello, P., Dell'Aversano, C., 2009. Gonyaulax spiniferafrom the Adriatic sea: Toxin production and phylogenetic analysis. Harmful Algae 8 (2), 279-290.

Ronquist, F., Huelsenbeck, J.P., 2003. MrBayes 3: bayesian phylogenetic inference under mixed models. Bioinformatics 19 (12), 1572-1574.

Rourke, W., Haigh, N., 2018. Occurrence of Yessotoxins in Canadian Shellfish from 20122017. The $18^{\text {th }}$ international conference on Harmful Algae from ecosystems to socioecosystems. pp. 533 Abstract book.

Sala-Pérez, M., Alpermann, T.J., Krock, B., Tillmann, U., 2016. Growth and bioactive secondary metabolites of arctic Protoceratium reticulatum (Dinophyceae). Harmful Algae 55, 85-96.

Salgado, P., Figueroa, R.I., Ramilo, I., Bravo, I., 2017. The life history of the toxic marin dinoflagellate Protoceratium reticulatum (Gonyaulacales) in culture. Harmful Algae 68, 67-81.

Salgado, P., Fraga, S., Rodríguez, F., Riobó, P., Bravo, I., 2018. Ceratocorys mariaovidiorumsp. nov. (Gonyaulacales), a new dinoflagellate species previously reported as Protoceratium reticulatum. J. Phychol. 54 (1), 126-137.

Satake, M., MacKenzie, L., Yasumoto, T., 1997. Identification of Protoceratium reticulatum as the biogenetic origin of yessotoxin. Nat. Toxins 5 (4), 164-167.

Satake, M., Ichimura, T., Sekiguchi, K., Yoshimatsu, S., Oshima, Y., 1999. Confirmation of yessotoxin and 45, 46, 47-trinoryessotoxin production by Protoceratium reticulatum collected in Japan. Nat. Toxins 7 (4), 147-150.

Scholin, C.A., Herzog, M., Sogin, M., Anderson, D.M., 1994. Identification of group- and strain-specific genetic markers for globally distributed Alexandrium (Dinophyceae). II. Sequence analysis of a fragment of the LSU rRNA gene. J. Phycol. 30 (6), 999-1011.

Skerratt, J.H., Bowman, J.P., Hallegraeff, G., 2002. Algicidal bacteria associated with blooms of a toxic dinoflagellate in a temperate Australian estuary. Mar. Ecol. Prog. Ser. 244, 1-15.

Sohm, J.A., Ahlgren, N.A., Thomson, Z.J., Williams, C., Moffett, J.W., Saito, M.A., Webb, 
E.A., Rocap, G., 2016. Co-occurring Synechococcus ecotypes occupy four major oceanic regimes defined by temperature, macronutrients and iron. ISME J. 10 (2), 333-345.

Stamatakis, A., 2006. RAxML-VI-HPC: maximum likelihood-based phylogenetic analyses with thousands of taxa and mixed models. Bioinformatics 22 (21), 2688-2690.

Struck, T.H., Feder, J.L., Bendiksby, M., Birkeland, S., Cerca, J., Gusarov, V.I., Kistenich, S., Larsson, K.-H., Liow, L.H., Nowak, M.D., 2017. Finding evolutionary processes hidden in cryptic species. Trends Ecol. Evol. 33 (3), 153-163.

Swofford, D.L., 2002. PAUP*. Phylogenetic Analysis Using Parsimony (* and Other Methods), Version 4. Sinauer Associates, Sunderland, Massachusetts.

Tillmann, U., Trefault, N., Krock, B., Parada-Pozo, G., De La Iglesia, R., Vasquez, M., 2017. Identification of Azadinium poporum (Dinophyceae) in the Southeast Pacific: morphology, molecular phylogeny, and azaspiracid profile characterization. J. Plankton Res. 39, 350-367.

Turner, A.D., Goya, A.B., 2015. Occurrence and profiles of lipophilic toxins in shellfish harvested from Argentina. Toxicon 102, 32-42.

Vanelslander, B., Creach, V., Vanormelingen, P., Ernst, A., Chepurnov, V.A., Sahan, E., Muyzer, G., Stal, L.J., Vyverman, W., Sabbe, K., 2009. Ecological differentiation between sympatric pseudocryptic species in the estuarine benthic diatom Navicula phyllepta (Bacillariophyceae). J. Phycol. 45 (6), 1278-1289.

Verleye, T.J., Mertens, K.N., Young, M.D., Dale, B., McMinn, A., Scott, L., Zonneveld, K.A.F., Louwye, S., 2012. Average process length variation of the marine dinoflagellate cyst Operculodinium centrocarpum in the tropical and Southern Hemisphere Oceans: assessing its potential as a palaeosalinity proxy. Mar. Micropaleontol. 86-87 (7), 45-58.

Vershinin, A., Moruchkov, A., Morton, S.L., Leighfield, T.A., Quilliam, M.A., Ramsdell,
J.S., 2006. Phytoplankton composition of the Kandalaksha Gulf, Russian White Sea: dinophysis and lipophilic toxins in the blue mussel (Mytilus edulis). Harmful Algae 5 (5), 558-564.

von Stosch, H.A., 1969. Dinoflagellaten aus der Nordsee I. Uber Cachonia niei Loeblich (1968), Gonyaulax grindleyi Reinecke (1967) und eine Methode zur Darstellung von Peridinnenpanzern. Helgol. Wiss. Meeredunters 19, 558-568.

Wall, D., Dale, B., 1966. Living fossils. Western Atlantic Plankton Nature 211. pp. 1025-1026.

Wall, D., Dale, B., 1967. The resting cysts of modern marine dinoflagellates and their palaeontological significance. Rev. Palaeobot. Palynol. 2 (1), 349-354.

Wall, D., Dale, B., 1968. Modern dinoflagellate cysts and evolution of the Peridiniales. Micropaleontology 14 (3), 265-304.

Whittaker, K.A., Rynearson, T.A., 2017. Evidence for environmental and ecological selection in a microbe with no geographic limits to gene flow. PNAS 12, 300-307.

Wołoszyńska, J., 1929. Dinoflagellatae der polnischen Ostsee sowie der an Piasnica gelegenen Sümpfe. Drukarnia i Litografja pf Jan Cotty.

Yap-Dejeto, L., Caryl, Y.D., Irene, L.T., Coleen, O.A., 2018. Pyrodinium bahamense and other dinoflagellate cysts in surface sediments of Cancabato Bay, Leyte, Philippines. Philipp. J. Sci. 147 (2), 209-220.

Yasumoto, T., Takizawa, A., 1997. Fluorometric measurement of yessotoxins in shellfish by high-pressure liquid chromatography. Biosci. Biotechnol. Biochem. 61 (10), 1775-1777.

Zonneveld, K.A., Marret, F., Versteegh, G.J., Bogus, K., Bonnet, S., Bouimetarhan, I., Crouch, E., de Vernal, A., Elshanawany, R., Edwards, L., et al., 2013. Atlas of modern dinoflagellate cyst distribution based on 2405 data points. Rev. Palaeobot. Palynol. 191, 1-197. 